\title{
Molecular and morphological analysis of the developing nemertean brain indicates convergent evolution of complex brains in Spiralia
}

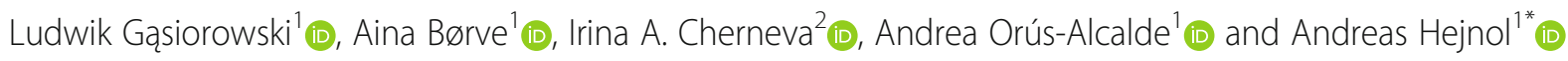

\begin{abstract}
Background: The brain anatomy in the clade Spiralia can vary from simple, commissural brains (e.g., gastrotrichs, rotifers) to rather complex, partitioned structures (e.g., in cephalopods and annelids). How often and in which lineages complex brains evolved still remains unclear. Nemerteans are a clade of worm-like spiralians, which possess a complex central nervous system (CNS) with a prominent brain, and elaborated chemosensory and neuroglandular cerebral organs, which have been previously suggested as homologs to the annelid mushroom bodies. To understand the developmental and evolutionary origins of the complex brain in nemerteans and spiralians in general, we investigated details of the neuroanatomy and gene expression in the brain and cerebral organs of the juveniles of nemertean Lineus ruber.
\end{abstract}

Results: In the juveniles, the CNS is already composed of all major elements present in the adults, including the brain, paired longitudinal lateral nerve cords, and an unpaired dorsal nerve cord, which suggests that further neural development is mostly related with increase in the size but not in complexity. The ultrastructure of the juvenile cerebral organ revealed that it is composed of several distinct cell types present also in the adults. The 12 transcription factors commonly used as brain cell type markers in bilaterians show region-specific expression in the nemertean brain and divide the entire organ into several molecularly distinct areas, partially overlapping with the morphological compartments. Additionally, several of the mushroom body-specific genes are expressed in the developing cerebral organs.

Conclusions: The dissimilar expression of molecular brain markers between L. ruber and the annelid Platynereis dumerilii indicates that the complex brains present in those two species evolved convergently by independent expansions of non-homologous regions of a simpler brain present in their last common ancestor. Although the same genes are expressed in mushroom bodies and cerebral organs, their spatial expression within organs shows apparent differences between annelids and nemerteans, indicating convergent recruitment of the same genes into patterning of non-homologous organs or hint toward a more complicated evolutionary process, in which conserved and novel cell types contribute to the non-homologous structures.

Keywords: CNS, Brain patterning, Neuroanatomy, Brain evolution, Mushroom body, Cephalic organ, Spiralia, Nemertea

\footnotetext{
* Correspondence: andreas.hejnol@uib.no

${ }^{1}$ Department of Biological Sciences, University of Bergen, Bergen, Norway

Full list of author information is available at the end of the article
}

C C The Author(s). 2021 Open Access This article is licensed under a Creative Commons Attribution 4.0 International License, which permits use, sharing, adaptation, distribution and reproduction in any medium or format, as long as you give appropriate credit to the original author(s) and the source, provide a link to the Creative Commons licence, and indicate if changes were made. The images or other third party material in this article are included in the article's Creative Commons. licence, unless indicated otherwise in a credit line to the material. If material is not included in the article's Creative Commons licence and your intended use is not permitted by statutory regulation or exceeds the permitted use, you will need to obtain permission directly from the copyright holder. To view a copy of this licence, visit http://creativecommons.org/licenses/by/4.0/ The Creative Commons Public Domain Dedication waiver (http://creativecommons.org/publicdomain/zero/1.0/) applies to the data made available in this article, unless otherwise stated in a credit line to the data. 


\section{Background}

Nemertea is a clade of ca. 1300 described species of unsegmented worms, which predominantly occur in marine environments [1-3]. Phylogenetically, they belong to the large animal group called Spiralia (together with, e.g., annelids, mollusks and flatforms) [4-12]; however, despite recent progress in molecular phylogenetics, their exact position on the spiralian tree of life remains controversial [6-8, 10, 13].

Most nemerteans are active predators, which hunt for their invertebrate prey using a specialized eversible proboscis, a morphological apomorphy of the clade [1, 1418]. This active lifestyle is accompanied by a relatively complex nervous system, which is coupled with an extensive complement of neuropeptides [19-21] and includes a large, multilobed brain (with two ventral and two dorsal lobes), a pair of lateral medullary nerve cords, vast peripheral network, and multiple specialized sensory organs $[17,18,21-31]$. Among the latter, the most conspicuous are the so-called cerebral (or cephalic) organs - paired structures of neurosecretory and either chemoor mechanosensory function, located on the lateral sides of the head [17, 18, 22-26, 30, 32-35]. The exact arrangement of the cerebral organs varies between nemertean clades from relatively simple, innervated ciliated pits present in some Tubulaniformes, to the complex neuroglandular organs structurally integrated with the brain and connected through the convoluted ciliated canal directly to the external environment in lineid heteronemerteans [17, 18, 22-26, 29, 30, 34, 35]. Yet, even in the species, in which the cerebral organs are well integrated into the brain, they initially develop from the separated ciliated canals that proximally fuse with the brain during ontogenesis [36-39]. The phylogenetic analysis of morphological traits in nemerteans indicated that cerebral organs were already present in the last common nemertean ancestor [23]. However, it remains unclear, whether the cerebral organs represent an autapomorphy of nemerteans or homologs to some organs present in other spiralians such as ciliated pits of flatworms [32, 40] or mushroom bodies of annelids [22, 41, 42]. The main argument for the homology of nemertean cerebral organs and ciliated pits present in some platyhelminths is the morphological similarity of both structures, which are composed of ciliated canal and the conspicuous neuroglandular, ganglion-like mass that connects directly to the brain $[32,40,43]$. On the other hand, the cerebral organs show some structural and functional similarities with the mushroom bodies of annelids [22] and both organs share high expression levels of proteins with the alleged function in memory and learning [42].

In the present study, we describe the detailed morphology of the nervous system and gene expression in the brain and cerebral organs of the juveniles of Lineus ruber (Müller, 1774), a directly developing lineid heteronemertean. $L$. ruber has been studied in the past for both adult morphology [21, 23, 25-28, 31-33] and some aspects of its development [31, 36, 44], including the molecular patterning of anterior-posterior axis, germ layers, and lateral nerve cords [38, 45]. Comparison of our data with the existing morphological descriptions of the adult nervous system in L. ruber [21, 23, 25-28, 31-33] and other closely related species allows a better understanding of the ontogeny of the complex nemertean nervous system. Additionally, juxtaposition of gene expression profiles in the developing brain of $L$. ruber with that of other Spiralia [45-53] can pinpoint similarities and differences in the molecular patterning of the spiralian brains in general, which in turn can inform evolution of the complex nemertean brain. Moreover, by comparing gene expression in cerebral organs of L. ruber and mushroom bodies of a comprehensively studied annelid $P$. dumerilii [54], we can provide new data to test the homology hypothesis of the cerebral organs of nemerteans and mushroom bodies of annelids.

\section{Results}

Morphology of the nervous system in the juvenile $L$. ruber The investigated juveniles of $L$. ruber were freshly hatched from the egg mass, 42 days after oviposition [38]. We visualized the nervous system of the juveniles by applying antibody staining against tyrosinated tubulin, FMRF-amide, and serotonin (5-HT), as well as Sytox green nuclear staining and fluorescent in situ mRNA hybridization of the choline acetyltransferase (ChAT), a genetic marker of the cholinergic neurons [55].

Forty-two-day-old juveniles have already all major components of the nervous system (Figs. 1 and 2), which is composed of (1) central nervous system (CNS) with brain, two lateral nerve cords (LNCs) connected by a postpharyngeal and posterior commissures and a single dorsal nerve cord (DNC); (2) stomatogastric nervous system (SNS), especially well developed in the pharyngeal region; (3) innervation of the proboscis; (4) network of fine peripheral nerves in the trunk; (5) a pair of large cerebral organs; and (6) other sensory structures such as frontal organs and frontal sensory nerves.

The brain is located anteriorly and is divided into four lobes: two ventral ( $v b l$, Figs. 1 and $2 \mathrm{~B}, \mathrm{~F}, \mathrm{H}, \mathrm{I})$ and two dorsal ones ( $d b l$, Figs. 1 and 2A, E). Each lobe is composed of the internal neuropile and the external layer of perikarya (Fig. 2C-F, J). Anteriorly both dorsal and ventral lobes are connected by dorsal ( $d b c$ Figs. 1 and 2A, C, E, G, I) and ventral ( $v b c$ Figs. 1 and $2 \mathrm{~B}, \mathrm{D}, \mathrm{F}, \mathrm{H}-\mathrm{J}$ ) brain commissures, respectively. Thus, the brain neuropile forms a ring around rhynchocoel and proboscis (Fig. 1). Posteriorly, each dorsal brain lobe is further divided into an inferior and a superior branch. The former 


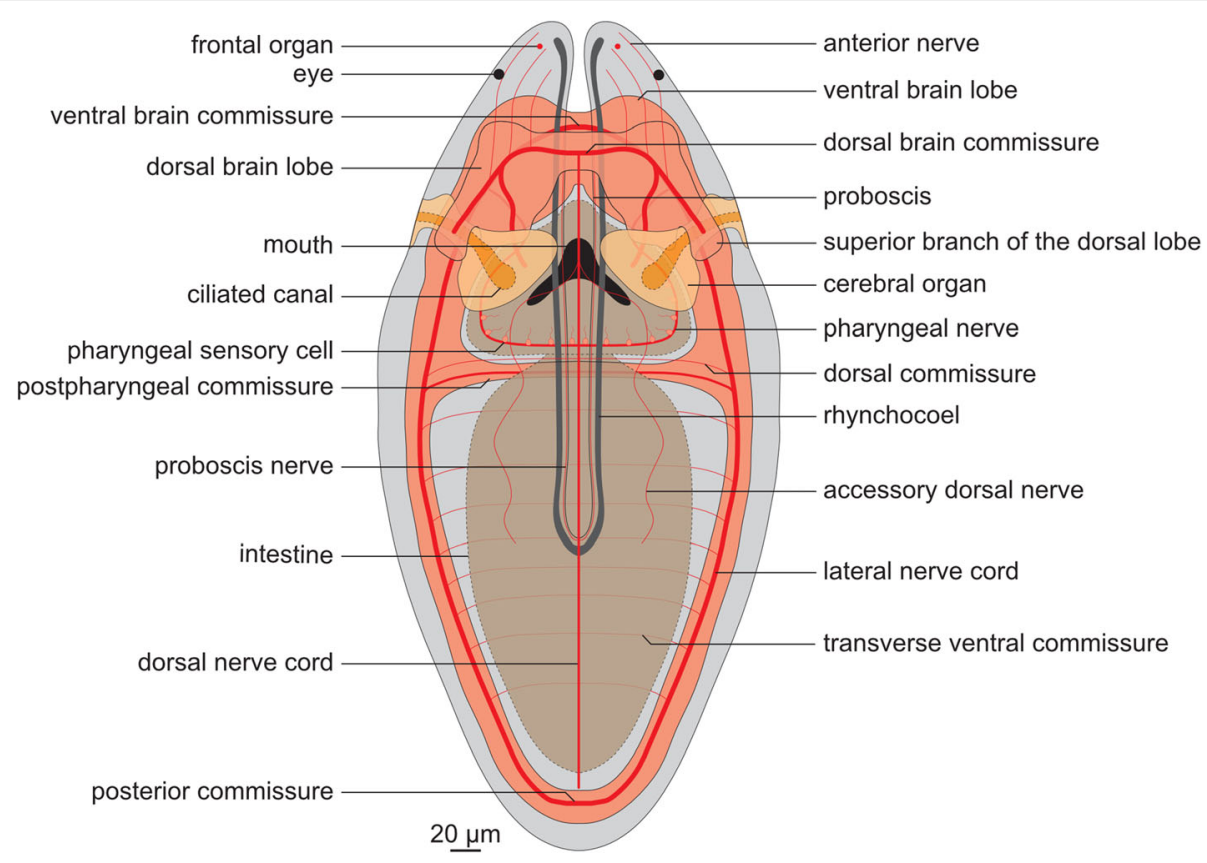

Fig. 1. Schematic drawing of the 42 -day-old juveniles of Lineus ruber. Anterior is to the top

connects directly to the cerebral organ (see below), while the latter ends blindly on the dorsal side of the animal (Figs. 1 and 2E). The neuropiles of the ventral lobes posteriorly give rise to the LNCs (Fig. 2D, H, J). FMRFamide-like immunoreactive (FLIR) perikarya and ChAT $T^{+}$ cells have been observed in both dorsal and ventral brain lobes (Fig. 2A-F), while serotonin-like immunoreactive (SLIR) perikarya are present only in the ventral lobes (Fig. 2H-J). Both dorsal and ventral commissures and neuropiles of all brain lobes are composed of FLIR, SLIR, and tyrosinated tubulin-like immunoreactive (TLIR) neurites (Fig. 2A-D, G-J).

Three longitudinal nerve cords originate from the brain: a pair of thick LNCs (lnc, Figs. 1 and 2A, B, D, F, $\mathrm{H}-\mathrm{J}$ ) and a finer, unpaired DNC ( $d n c$, Figs. 1 and $2 \mathrm{~A}, \mathrm{G}$, I). The LNCs are composed of an external layer of perikarya and an internal neuropile (and hence represent medullary nerve cords [56]). The neuropiles are densely packed with TLIR, SLIR and FLIR neurites $(\operatorname{lnc}$, Fig. 2A, $\mathrm{B}, \mathrm{D}, \mathrm{H}-\mathrm{J}$ ), while numerous $C h A T^{+}$neuronal cell bodies as well as more sparsely distributed FLIR and SLIR perikarya are mostly present in the anterior section of each LNC (Fig. 2B, D, F, I, J). The LNCs are connected behind the pharynx by a medullary postpharyngeal commissure (ppc, Fig. 2B, F, H, J), which is composed of TLIR and SLIR neurites as well as few SLIR and numerous $\mathrm{ChAT}^{+}$perikarya (Fig. 2F, J). At the end of the animal body, both LNCs converge in a posterior commissure ( $p c$, Figs. 1 and $2 \mathrm{~B}, \mathrm{H}$ ), which shows the same immunoreactivity patterns as neuropiles of LNCs.
The DNC originates from the dorsal brain commissure. Compared to the LNCs, it is much finer and does not seem to be associated with any perikarya (Fig. 2A, G, I). It is composed of only a few TLIR and SLIR neurites, while anteriorly, a pair of fine FLIR dorsal accessory nerves branch out from it ( $a d n$, Figs. 1 and 2A). At the level of the pharynx, a fine, SLIR and TLIR dorsal commissure connects dorsal and lateral nerve cords $(d c$, Figs. 1 and 2I).

The SNS is composed of thick TLIR, FLIR, and SLIR pharyngeal nerves, which originate from the ventral brain lobes and meander around the pharynx (phn, Figs. 1 and 2C, D, J). Numerous sensory FLIR and SLIR cells are located along the pharyngeal nerves (Fig. 1; double arrowheads Fig. 2D, J). Each of those cells has a basal connection to the pharyngeal nerve and an apical process pointing toward the pharyngeal lumen.

Some neural structures are also associated with the proboscis. Two longitudinal TLIR and FLIR nerves extend along the proboscis ( $p n$, Figs. 1 and 2C); however, their exact origin in the brain remains unclear. Scattered $C h A T^{+}$cells, of probably sensory function, are present in the epidermis of the proboscis (yellow arrowheads, inset in Fig. 2E).

The extensive network of peripheral nerves was detected in the trunk, especially evident on the ventral side of the animal. It is composed of regular transverse ventral TLIR commissures (Fig. 1; arrowheads, Fig. 2B), some of which are additionally SLIR (arrowheads, Fig. $2 \mathrm{H}-\mathrm{J})$. A less regular network of SLIR intraepidermal 

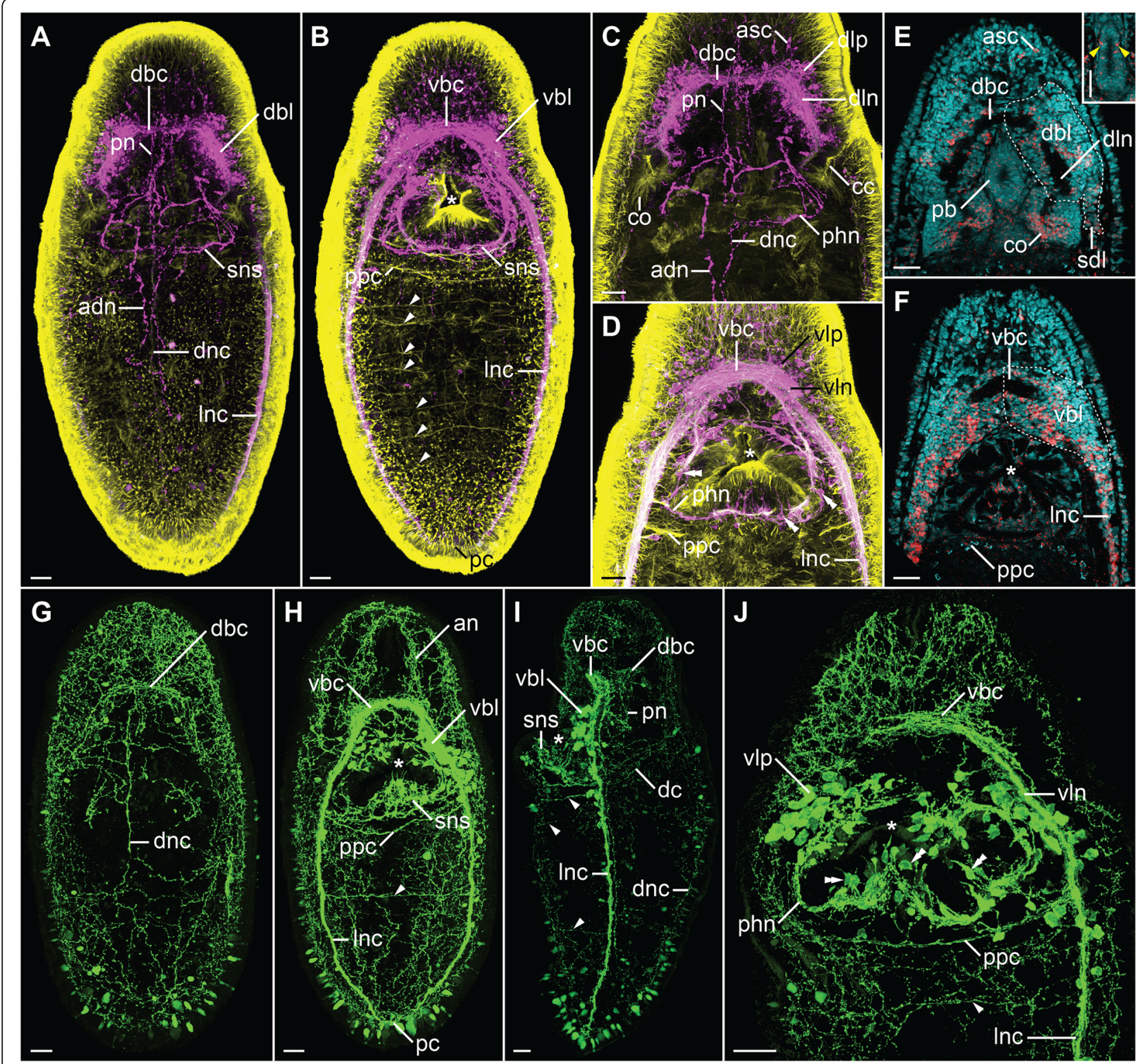

Fig. 2. Morphology of the nervous system in 42 -day-old juveniles of $L$. ruber visualized with CLSM and antibody staining against tyrosinated tubulin (yellow, A-D), FMRF-amide (magenta, $\mathbf{A}-\mathbf{D}$ ), and serotonin (green, $\mathbf{G}-\mathbf{J}$ ) as well as Sytox green nuclear staining (cyan, E, F) and in situ hybridization with probe against choline acetyltransferase (red, E, F). Entire animal in dorso-ventral projection with a focus on dorsal (A, G) and ventral $(\mathbf{B}, \mathbf{H})$ structures; anterior part of the animal in dorso-ventral projection with a focus on dorsal $(\mathbf{C}, \mathbf{E})$ and ventral $(\mathbf{D}, \mathbf{F}, \mathbf{J})$ structures; inset in E shows ChAT expression in the proboscis (yellow arrowheads); I lateral projection of the entire animal. Anterior is to the top on all panels. Scale bars $20 \mu \mathrm{m}$. adn, accessory dorsal nerve; an, anterior nerve; asc, anterior sensory cell; cc, ciliated canal; co, cerebral organ; dbc, dorsal brain commissure; dbl, dorsal brain lobe; dc, dorsal commissure; dln, dorsal lobe neuropile; dlp, dorsal lobe perikaryon; dnc, dorsal nerve cord; Inc, lateral nerve cord; pb, proboscis; pc, posterior commissure; phn, pharyngeal nerve; pn, proboscis nerve; ppc, postpharyngeal commissure; sdl, superior branch of the dorsal lobe; sns, stomatogastric nervous system; vbc, ventral brain commissure; vbl, ventral brain lobe; vln, ventral lobe neuropile; vlp, vetral lobe perikaryon. White arrowheads indicate transverse ventral commissures, double white arrowheads pharyngeal sensory cells, and asterisks the mouth opening.

neurites is present on both dorsal and ventral sides of the juvenile (Fig. 2G-J).

A pair of conspicuous cerebral organs is located on the lateral sides of the head, just behind the brain $(c o$, Figs. 1 and 2C, E). More details of their morphology can be found in the following section. Other sensory structures, detected in addition to the cerebral organs, includes FLIR and ChAT anterior sensory cells (asc, Figs. 1 and $2 \mathrm{C}, \mathrm{E}$ ), which likely contribute to the socalled frontal organs [22, 25-27], and numerous SLIR cephalic nerves extending anteriorly from the brain (an, Figs. 1 and 2H). Although 42-day-old juveniles already 
possess rudiments of eyespots [38], we were not able to conclusively detect them in our investigation.

EdU staining in 60-day-old juveniles showed that most of the brain cells at this later developmental stage are not mitotically active in contrast to the cells in other organs, such as proboscis, rhynchocoel, or cerebral organs (Fig. 3A and B).

\section{Detailed morphology of the cerebral organs}

Each cerebral organ is composed of two parts: a distal ciliated canal (cc, Figs. 1, 2C, and 4B, C), which opens to

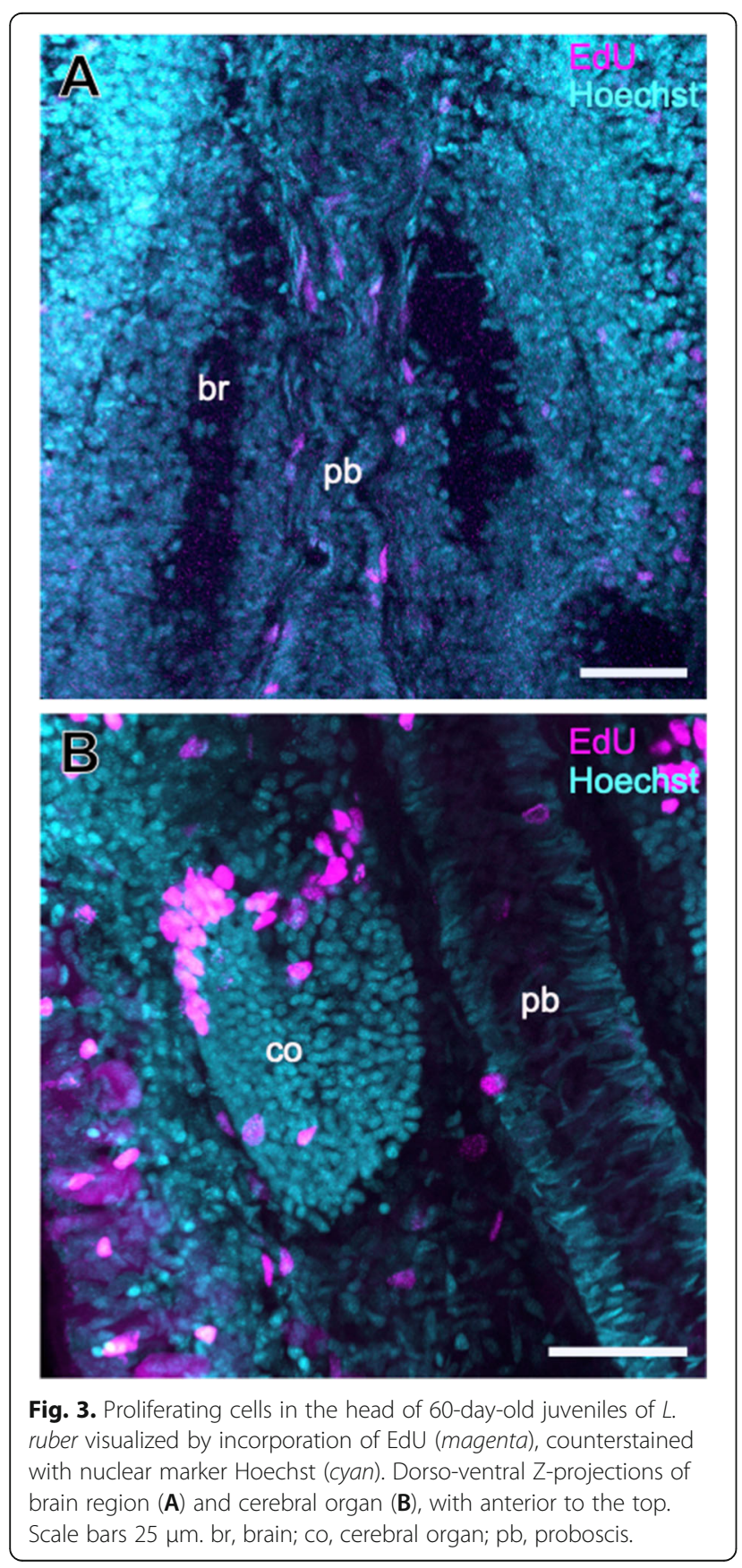

the exterior on the side of the head (in the posterior part of the so-called lateral cephalic slit), and a proximal neuroglandular portion (co, Figs. 1 and 2C). The lumen of the ciliated canal is slightly curved in 42-day-old juveniles, but the characteristic triple right-angle bends, present in the adult lineids [32-34] are not yet evident (cc, Fig. 2C). The ciliated canal connects the external environment with the neuroglandular part, which itself is firmly attached to the inferior branch of the dorsal brain lobe (Figs. 1, 2E, and 4B, C). A thick TLIR and FLIR neurite bundles of cerebral organ extend from the most posterior part of the dorsal lobe neuropile and penetrates the neuroglandular portion of the cerebral organ (con, Fig. 4C). We detected a few FLIR and much more numerous $\mathrm{ChAT}^{+}$cells in the neuroglandular portion of the organ (arrowhead, Fig. 4C and arrow, Fig. 4B, respectively), while serotonin-like immunoreactivity was not detected (data not shown).

To gain further insight into the morphology of the cerebral organs, we supplemented the aforementioned confocal laser scanning microscopy (CLSM) based methods with ultrathin sectioning of resin-embedded specimens (60-day-old juveniles) and TEM examination of the organ. That allowed us to describe the fine structure of the cerebral organ and ultrastructure of the particular cell types contributing to it. Since all detected cell types correspond directly to the ones described previously by Ling in his investigation of adult $L$. ruber [32], we adopted the terminology used therein.

We investigated cross-sections through the neuroglandular portion of the cephalic organ. The mass of the organ is located between the proboscis and the lateral nerve cords (Fig. 4A) and it is penetrated by both the cerebral organ nerve (con) and the ciliated canal $(c c)$. The ciliated canal is divided into two parallel parts: a larger major ciliated canal $(m j c)$ and a smaller minor ciliated canal $(m n c)$ (Fig. 4G). Based on the ultrastructure, six distinct cell types can be distinguished in the sectioned area of the cerebral organ. The most numerous are cells corresponding to the type 1 bipolar cells $(b c 1)$ described by Ling [32] that constitute the majority of the neuroglandular mass (Fig. 4D, E). Their relatively small nuclei are roughly polygonal in cross-section and have dark nucleoplasm with the irregularly distributed chromatin (Fig. 4D). The very similar cells, type 2 bipolar cells following classification by Ling [32], are much less frequent $(b c 2$, Fig. $4 \mathrm{E})$. They have the same nuclear size and shape as well as chromatin arrangement as $b c 1$, but their nucleoplasm is electron-translucent (Fig. 4E). A relatively few ganglion cells $(g c)$ are present in the vicinity of the nerve of cerebral organ (Fig. 4D, E). Those cells have large nuclei that are almost circular in section and display an electron-translucent nucleoplasm with nucleolus and irregularly distributed chromatin (Fig. 


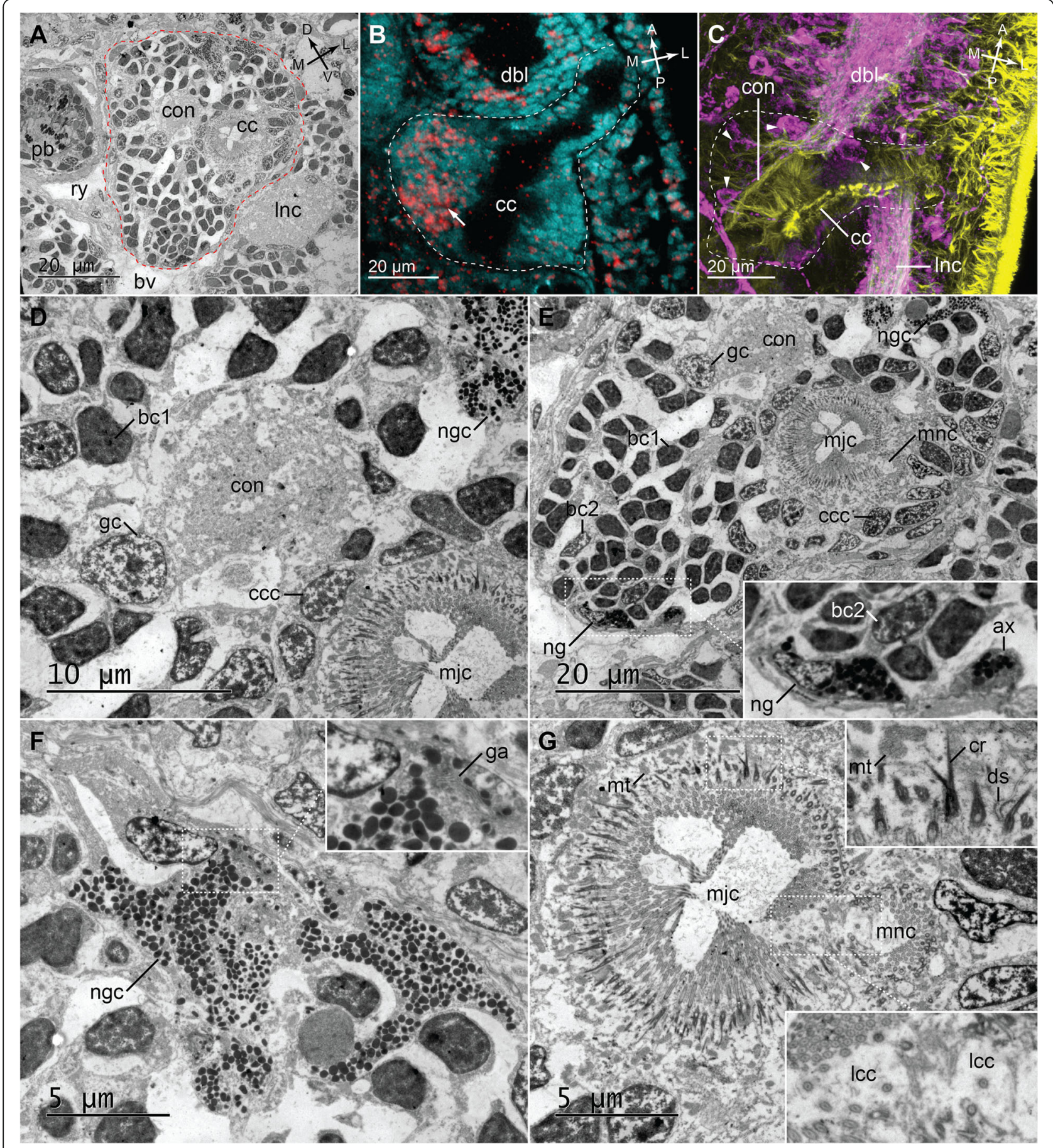

Fig. 4. Detailed morphology of cerebral organs in juveniles of L. ruber. TEM micrographs of cerebral organs in 60-day-old juvenile, showing crosssection $(\mathbf{A})$ and details of particular regions of the organ (D-G). Z-projections of cerebral organs in 42-day-old juveniles visualized with Sytox green nuclear staining and in situ hybridization with probe against ChAT (cyan and red, respectively; B) and antibodies against FMRF-amide and tyrosinated tubulin (magenta and yellow, respectively; $\mathbf{C}$ ). Cerebral organs are outlined in red (A) and white (B, C). Orientation inside the animal is indicated in the top-right corners in $\mathbf{A}-\mathbf{C}$ ( $\mathbf{A}$, anterior; $\mathrm{P}$, posterior; $\mathrm{D}$, dorsal; $\mathbf{V}$, ventral; $\mathbf{M}$, median; $\mathrm{L}$, lateral). Micrographs in $\mathbf{D}-\mathbf{G}$ show magnified areas of $\mathbf{A}$. White outlined boxes on $\mathbf{E}, \mathbf{F}$, and $\mathbf{G}$ indicate areas magnified in corresponding insets. ax, neuroglia axon; bc1, bipolar cell type1; bc2, bipolar cell type 2; bv, blood vessel; cc, ciliated canal; ccc, ciliated canal cell; con, cerebral organ nerve; cr, ciliary rootlet; dbl, dorsal brain lobe; ds, desmosome; ga, Golgi apparatus; gc, ganglion cell; Icc, dilated cilia of lappet cell; Inc, longitudinal nerve cord; mjc, major ciliated canal; mnc, minor ciliated canal; mt, mitochondrium; ng, neuroglia; ngc, neuroglandular cell; pb, proboscis; ry, rhynchocoel. White arrow indicates ChAT ${ }^{+}$cells in cerebral organ, and white arrowhead FMRF-amide-like immunoreactivity in cerebral organ 


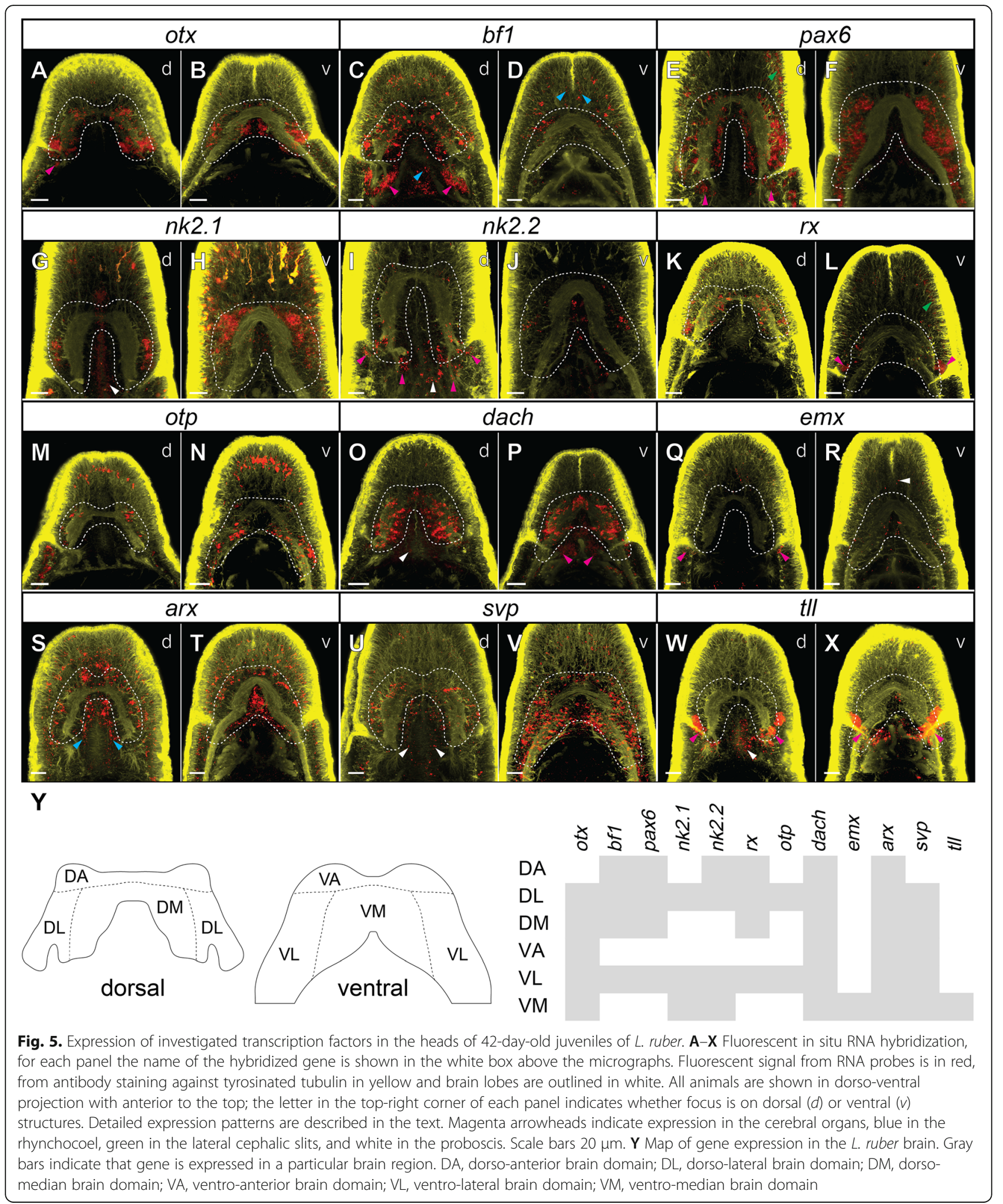

4D). On the dorso-lateral side of the cerebral organ a single, large, irregularly shaped cell (ngc, Fig. 4D-F) exhibits the same ultrastructure as neuroglandular cells, identified by Ling [32]. Its branching, spacious cytoplasm is filled with numerous electron-dense inclusions. Additionally, the Golgi apparatus was observed in the cytoplasm ( $g a$; inset, Fig. 4F). A single cell that was observed on the opposite, ventro-median side of the organ $(n g$, 
Fig. 4E), corresponds ultrastructurally to the neuroglial cell type observed in adults [32]. It is less voluminous than the neuroglandular cell, has a darker cytoplasm, and is more densely packed inclusions. A cross-section through the cellular process with the similar ultrastructure (corresponding to the neuroglial axons described by Ling in adults [32]) is visible ca. $3 \mu \mathrm{m}$ from the neuroglial cell body ( $a x$; inset, Fig. 4E). The cells of the ciliated canal (ccc) represent the last cell type visible on the examined cross-section (Fig. 4D, E). The apical surface of those cells is densely packed with cilia, which are equipped with asymmetrically bifurcating ciliary rootlets (cr; inset, Fig. 4G). Numerous mitochondria are present just below the ciliary rootlets, while the lateral sides of the cells are connected apically by desmosomes ( $m t$ and $d s$, respectively; inset, Fig. 4G). The cilia on the border of the major and the minor canals $(l c c)$ are characteristically dilated and form a septum that divides both canals (inset, Fig. 4G). Those cilia indicate the presence of the seventh cell type, lappet cells, although the cells themselves could not be distinguished from the other cells of the ciliated canal.

EdU staining of mitotically active cells in the 60-dayold juveniles indicted intensive proliferation in cerebral organs, especially in its anterior region (Fig. 3B).

\section{Gene expression in the head}

We investigated expression of 12 transcription factors (TFs), which have a role in CNS development of many bilaterians. Those genes include the conserved general brain markers (otx, bf 1 ), genes involved in brain regional specification (pax6, nk2.1, nk2.2, $r x$, otp), and other neural genes, which are co-expressed in the annelid mushroom bodies (dach, emx, arx, svp, tll).

Expression of otx has been previously described for earlier developmental stages of $L$. ruber, in which the gene has a general anterior expression in the head [38]. In the 42-day-old juveniles, which we investigated, the gene otx is predominantly expressed in the brain (Fig. $5 \mathrm{~A}, \mathrm{~B}$ ) and cerebral organs (Figs. 5A and 6B). In the brain, otx is broadly and uniformly expressed both in dorsal and ventral lobes (Fig. 5A, B). In the cerebral organs, it is also widely expressed, both in the ciliated canal and neuroglandular part (Fig. 6B). A similar expression pattern of otx in the brain and cerebral organs has been also reported from developing juveniles of closely related Lineus viridis [57].

$b f 1$ is expressed in the brain, cerebral organs, and scattered cells in the anterior epidermis and in the rhynchocoel (Figs. 5C, D and 6C). In the brain, bf1 is broadly expressed in the dorsal lobe (Fig. $5 \mathrm{C}$ ), but in the ventral one it is only detectable in the lateral clusters of cells (Fig. 5D). The detected expression of $b f 1$ in the cerebral organ is very strong in the neuroglandular part, whereas we did not detect a signal in the ciliated canal (Fig. 6C).

Expression of pax6, $n k 2.1$, and $n k 2.2$ has been previously investigated in the juveniles of $L$. ruber in relation to the nerve cord patterning [45]; however, the expression of those three genes in the brain was not described in the details that we provide here. In the head region, pax6 is expressed in the brain and the epidermal cells of the lateral cephalic slits and in the cerebral organs (Figs.

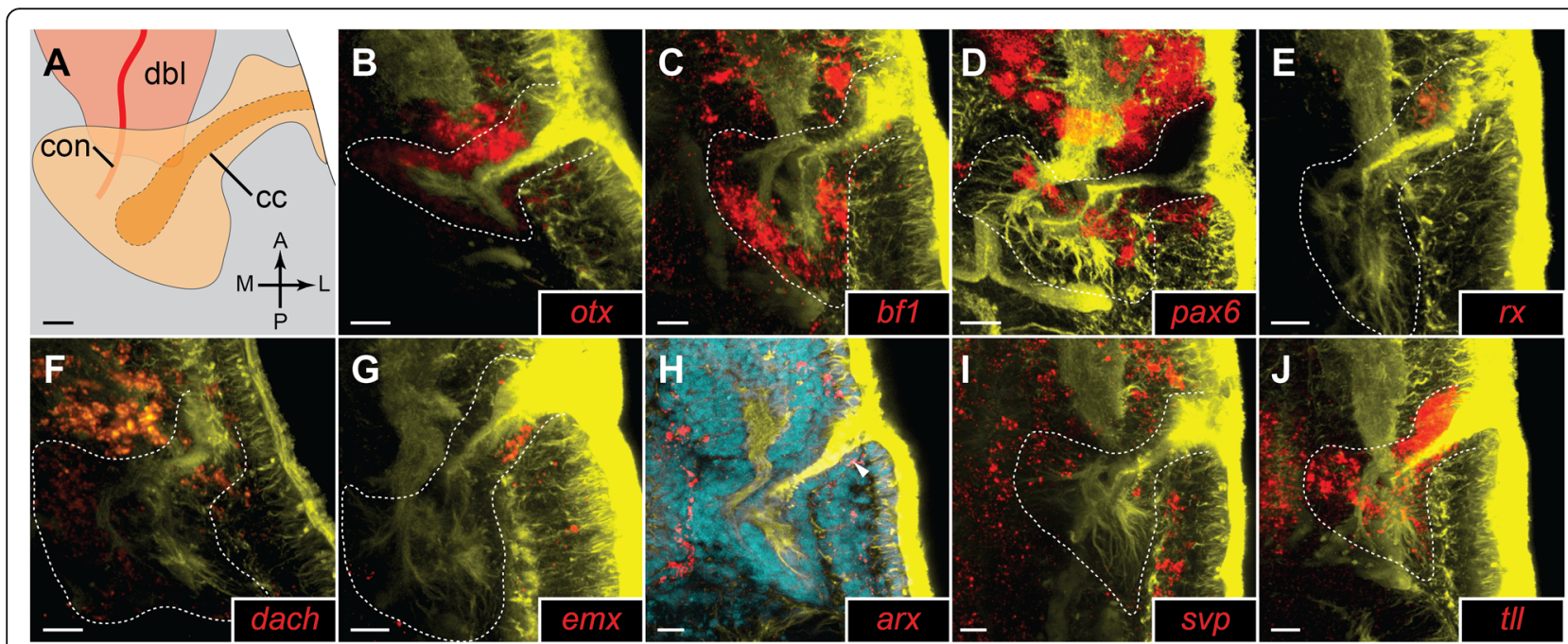

Fig. 6. Details of gene expression in the cerebral organs of 42-day-old juveniles of $L$. ruber. A Schematic drawing of the cerebral organ and accompanying neural structures, orientation in the animal is indicated in bottom-right corner ( $\mathrm{A}$, anterior; $\mathrm{P}$, posterior; $\mathrm{M}$, median; $\mathrm{L}$, lateral). $c c$, ciliated canal; con, cerebral organ nerve; dbl, dorsal brain lobe. B-J Fluorescent in situ RNA hybridization; for each panel, the name of hybridized gene is provided in the bottom-right corner. Fluorescent signal from RNA probes is in red, from antibody staining against tyrosinated tubulin in yellow, and from Sytox green nuclear staining in cyan; cerebral organs are outlined in white. The detailed expression patterns are described in the text. White arrowhead indicates $\operatorname{arx}^{+}$cell at the posterior side of the ciliated canal opening. Scale bars $10 \mu \mathrm{m}$ 
$5 \mathrm{E}, \mathrm{F}$ and $6 \mathrm{D})$. The gene is broadly expressed in the dorsal lobes (Fig. 5E), while in the ventral ones its expression is restricted to the lateral portions of the brain (Fig. $5 \mathrm{~F})$. In the cerebral organs, the gene is expressed in the stripe of cells on the lateral side of the neuroglandular portion (Fig. 6D).

In the head region, $n k 2.1$ is expressed in the brain and proboscis (Fig. 5G, H). In the dorsal lobes, the gene is expressed only in the small lateral clusters of cells (Fig. $5 \mathrm{G}$ ), while on the ventral side the gene is broadly expressed both in the median and lateral domains (Fig. $5 \mathrm{H}) . n k 2.1$ is not expressed in the cerebral organs.

$n k 2.2$ is expressed in the brain, proboscis, and cerebral organs (Fig. 5I, J). In the dorsal brain lobes, the gene is expressed in large clusters of posterior cells and in scattered anterior domains (Fig. 5I), whereas ventrally, it is expressed in median and lateral cell clusters (Fig 5J). Expression in the cerebral organs is detected in isolated domains of both ciliated canal and neuroglandular portion (Fig. 5I).

The gene $r x$ is expressed in the brain, anterior sensory organs, and epidermal cells of lateral cephalic slits and in the cerebral organs (Figs. 5K, L and 6E). Dorsally, the gene is expressed in isolated cells distributed relatively uniformly throughout the brain lobes (Fig. 5K). In the ventral lobes, $r x$ is expressed only in a pair of posterolateral cell clusters (Fig. 5L). In the cerebral organs, the gene is specifically expressed in the cluster of epidermal cells at the anterior side of the ciliated canal opening (Fig. 6E).

Expression of $o t p$ is detectable in the brain, LNCs, and numerous anterior sensory cells (Fig. 5M, N). In the dorsal lobes, the gene is expressed only in a relatively few lateral cells (Fig. 5M), while ventrally it is also predominantly expressed in the lateral cells of the brain lobes, but its expression was also detected in the more median cells contributing to the mouth innervation and anterior part of the LNC (Fig. 5N).

In the head region, the gene dach is expressed in the brain, cerebral organs, proboscis, and few isolated anterior cells (Figs. 5O, P and 6F). The expression in the brain is rather uniform and transcripts of the gene were detected in all regions of both dorsal and ventral lobes (Fig. 5O, P). In the cerebral organs, the gene was detected in some of the cells of both the ciliated canals and the neuroglandular portion (Fig. 6F).

Expression of the gene emx was detected in the brain, cerebral organs, proboscis, and cells along anterior cephalic nerves (Figs. 5Q, R and 6G). In the brain, the gene is expressed only in a few cells in the ventro-median domain (Fig. 5R). In the cerebral organs, the gene transcripts were detected in the cells at the posterior side of the ciliated canal opening and in a single median cell in the neuroglandular part of the organ (Fig. 6G).
The TF arx has a broad expression in the anterior body of the juvenile L. ruber. It is expressed in the brain, rhynchocoel, epidermal cells, and anterior sensory cells and in the cerebral organs (Figs. 5S, T and 6H). In both dorsal and ventral brain lobes, its expression was detected in numerous anterior, lateral and median cells (Figs. 5S, T). In contrast, the expression in the cerebral organs was restricted to a single cell at the posterior side of the ciliated canal opening (Fig. 6H).

The gene $s v p$ is also broadly expressed in anterior structures; its expression was detected in the brain, cerebral organs, LNCs, anterior sensory cells, and proboscis (Figs. $5 \mathrm{U}, \mathrm{V}$ and $6 \mathrm{I}$ ). In the dorsal brain lobes, it is expressed in cells distributed through the lateral and median regions (Fig. 5U), while ventrally it is expressed uniformly in the entire ventral lobes (Fig. 5V). In the cerebral organs, expression of $s v p$ was detected in some anterior and lateral cells of the neuroglandular part (Fig. 6I).

Transcripts of the gene $t l l$ were detected in the brain, cerebral organs, and proboscis (Figs. 5W, X and 6J). Expression in the brain was restricted just to a few cells posteriorly to the ventral commissure (Fig. 5X). Signal from the probes against $t l l$ was extremely strong in the cerebral organs (Fig. 5W, X) and was observed throughout the entire structure in cells of both the ciliated canal and the neuroglandular portion (Fig. 6J).

The brain of the juvenile L. ruber is divided by commissures and lobe neuropiles into eight regions: unpaired dorso-anterior, dorso-median, ventro-anterior, and ventro-median regions as well as paired dorsolateral and ventro-lateral areas (Fig. 5Y). Mapping of the above-described gene expression patterns onto those brain domains revealed that most of the regions express unique combination of the TFs (Fig. 5Y). The only brain regions which seem to express the same sets of TFs are dorsal and ventral lateral domains (Fig. 5Y).

\section{Gene co-expression during brain development}

To further explore co-expression of some of the TFs in the brain, we performed double in situ hybridization of the selected brain patterning genes ( $n k 2.1, n k 2.2$, pax6 and $r x$ ). In addition to the investigation of 42-day-old juveniles, we also examined co-expression of those genes in the earlier developmental stage, 25-day-old early juveniles, in order to test whether the observed co-expression patterns are conserved throughout ontogenesis.

The CNS of 25-day-old juveniles shows much simpler morphology when compared to the hatched juveniles (Fig. 7A). It is composed of LNCs, which merge anteriorly in the brain with two commissures - a thicker ventral and thinner dorsal - that form a ring-shaped neuropile around the developing proboscis rudiment. At this developmental stage, the brain is not yet divided into the dorsal and ventral lobes and the cerebral organs 


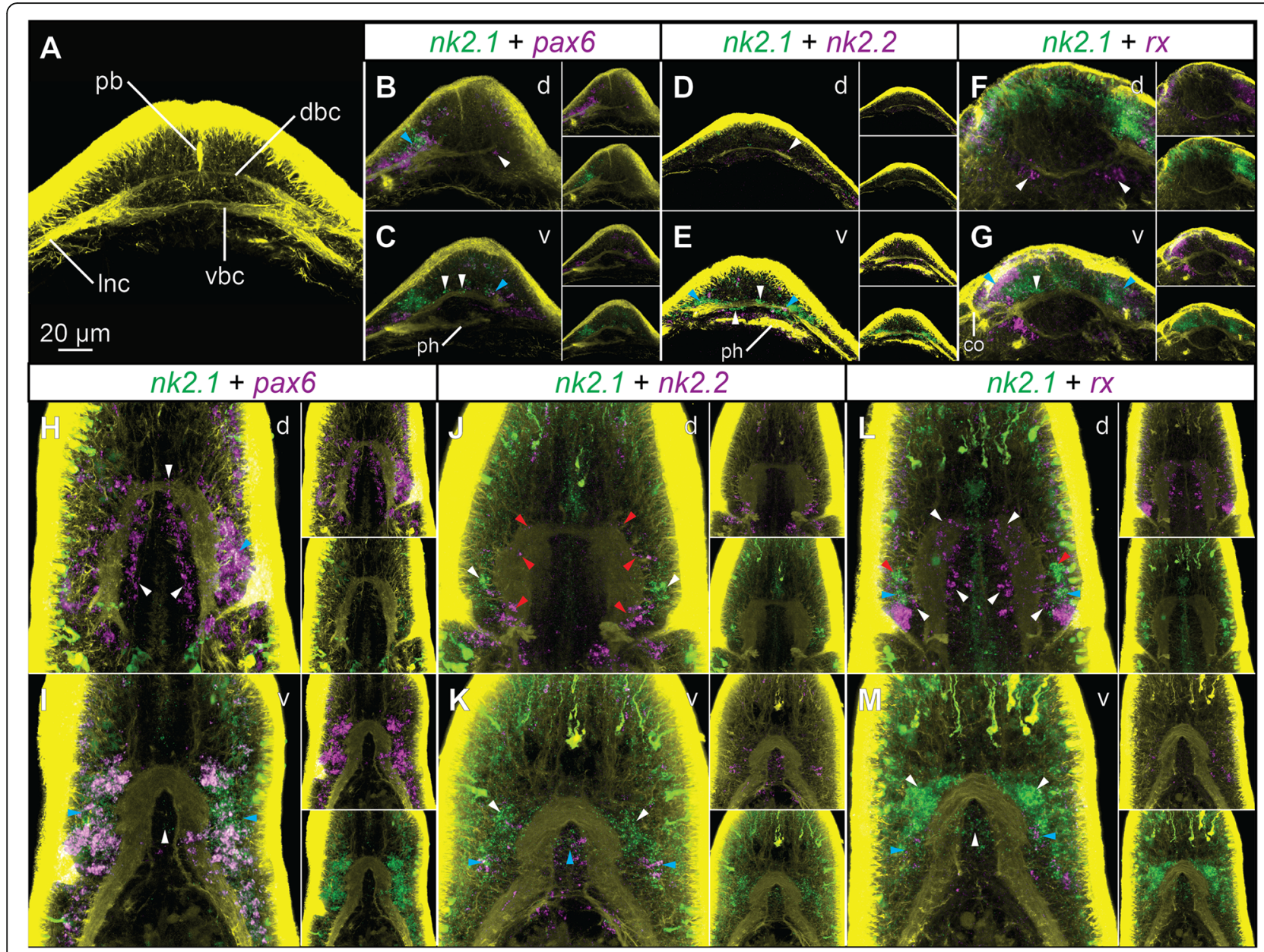

Fig. 7. Co-expression of brain patterning genes in the developing brain of L. ruber. A Morphology of the brain in 25-day-old juveniles. B-G Coexpression in the brain of 25-day-old juveniles. $\mathbf{H}-\mathbf{M}$ Co-expression in the brain of 42 -day-old juveniles. Fluorescent signal from antibody staining against tyrosinated tubulin is in yellow and from RNA probes is in magenta and green. For each panel, the color-coded names of hybridized genes are shown in the white box above the micrographs. White and red arrowheads indicate exclusive expression of one of the hybridized genes, blue arrowheads indicate co-expression. All animals are shown in dorso-ventral projection with anterior to the top; the letter in the topright corner of each panel indicates whether the focus is on dorsal $(d)$ or ventral $(v)$ structures. Micrographs on $\mathbf{B}-\mathbf{M}$ are not to the scale. co, cerebral organ; dbc, dorsal brain commissure; Inc, lateral nerve cord; pb, proboscis rudiment; ph, pharynx

are not fully formed, being mainly composed by the ciliated canal, that is not directly connected with the brain [38].

In the brain of 25 -day-old juvenile, $n k 2.1$ is expressed along the ventral commissure and in the lateral parts of the brain (Fig. 7B, C, E, G). In its lateral domains, the gene is co-expressed with pax6 (blue arrowheads, Fig. $7 \mathrm{~B}, \mathrm{C}$ ) and $r x$ (blue arrowheads, Fig. 7G). Additionally, some of the lateral $n k 2.1^{+}$cells also express $n k 2.2$ (blue arrowheads, Fig. 7E). The more median $n k 2.1^{+}$cells that are associated with the ventral commissure are devoid of pax6, $n k 2.2$ and $r x$ expression (white arrowheads, Fig. $7 \mathrm{C}, \mathrm{E}, \mathrm{G})$. In addition to the expression in lateral domains, pax6, $n k 2.2$, and $r x$ are also expressed in cells associated with the dorsal commissure, which do not coexpress $n k 2.1$ (white arrowheads, Fig. 7B, D, F).
The analysis of gene co-expression in the 42-day-old juveniles generally corroborates the expression map based on single gene hybridization; however, it allows more detailed description of the brain molecular regionalization. In the dorsal brain, pax6 is broadly expressed in the lateral and median domains (white arrowheads, Fig. $7 \mathrm{H}$ ) and only small clusters of lateral cells co-express pax6 and $n k 2.1$ (blue arrowhead, Fig. $7 \mathrm{H}$ ). In the ventral lobes, the lateral cells co-express pax6 and $n k 2.1$ (blue arrowheads, Fig. 7I), while cells in the median domain express only $n k 2.1$ (white arrowhead, Fig. 7I). $n k 2.1$ and $n k 2.2$ are not co-expressed in the dorsal brain (Fig. 7J). $n k 2.1$ is expressed in the most lateral cells of the dorsal brain (white arrowheads, Fig. 7J), while $n k 2.2$ is expressed in the large, more posterior domains and in scattered cells in the anterior brain region (red 
arrowheads, Fig. 7J). In the ventral brain, both genes are co-expressed in the postero-lateral and median domains (blue arrowheads, Fig. 7K); however, $n k 2.1$ has much broader ventral expression with many $n k 2.1^{+}$cells devoid of $n k 2.2$ expression (white arrowheads, Fig. $7 \mathrm{~K}$ ). $r x$ is expressed in scattered anterior, median, and lateral cells in the dorsal brain, which do not co-express $n k 2.1$ (white arrowheads, Fig. $7 \mathrm{~L}$ ). In the lateral parts of the brain, some cells co-express $r x$ and $n k 2.1$ (blue arrowheads, Fig. 7L), while some $n k 2.1^{+}$cells do not express $r x$ (red arrowheads, Fig. 7L). In the ventral brain, the antero-lateral and median $n k 2.1^{+}$cells do not express $r x$ (white arrowheads, Fig. $7 \mathrm{M})$, while small clusters of postero-lateral cells coexpress both genes (blue arrowheads, Fig. 7M).

On the whole, comparison of gene co-expression between 25- and 42-day-old juveniles shows that the general molecular patterning of the developing brain is retained throughout development. The ventro-median region expresses $n k 2.1$ but not pax6 nor $r x$. The lateral brain includes cells co-expressing $n k 2.1$ with pax6, $n k 2.2$, and $r x$, while dorsal brain is mainly composed of pax6-, nk2.2-, and $r x$-positive cells which do not coexpress $n k 2.1$. The differences between both life stages are primarily associated with the more complex architecture of the brain in 42-day-old juveniles, which requires a more intricate developmental control; nevertheless, the most general gene expression patterns are conserved.

\section{Discussion}

\section{Comparison of juvenile and adult morphology}

Nervous system has been investigated in great detail in adult Lineus ruber [21, 23, 25-28, 31-33] and Lineus viridis [21-23, 27], a morphologically similar species that belongs to the same species complex $[58,59]$. Comparison between the juvenile and adult worms reveals that all major nervous structures described in the adults are already present in the 42-day-old juveniles, indicating that at this stage the general neuroarchitecture is already fully formed and that further development is mostly related with increase in the size but not morphological complexity. The same pattern is observed in number and diversity of cell types contributing to the cerebral organs. There are, however, some minor differences in immunoreactivity patterns between both life stages. For instance, SLIR perikarya have been reported in the dorsal brain ganglia of adult L. ruber [26], while we observed immunoreactivity against serotonin only in the ventral brain ganglia of the juveniles (Fig. 2I). This indicates that even though the general morphology of the brain is already established at the moment of hatching, the following growth of the brain is not only purely quantitative, but also new cell types are added in certain brain regions or some of the neurons change their immunoreactivity during further development. Moreover, staining of mitotically active cells showed that in 60-dayold juveniles cell proliferation in the brain is lower than in the other organs, while the cells of the cerebral organs are still intensively dividing (Fig. 3), indicating allometric growth of the CNS.

The major postpharyngeal commissure, which ventrally connects the lateral nerve cords, is the only juvenile neural structure which does not correspond directly to any of the elements of the adult nervous system of $L$. ruber [23, 25, 31] or, to our best knowledge, of any other nemertean, which nervous system has been studied thus far (e.g., $[17,18,22-24,30,60-64])$. In adult nemerteans, the lateral nerve cords are connected by numerous delicate ventral commissures that are composed just of bundles of neurites and are considered part of the peripheral nervous system. Conversely, the postpharyngeal commissure described in this study is associated with few SLIR and numerous $C h A T^{+}$perikarya and has typical medullary arrangement, markedly different from the remaining ventral commissures (Figs. 1 and 2). There are two possibilities to explain this discrepancy in morphology of both stages: either the commissure degenerates during ontogeny or, due to the allometric growth, becomes much less prominent in later developmental stages and was overlooked in previous investigations.

Nevertheless, the observation of the postpharyngeal ventral commissure in a nemertean is interesting since similar structures are present in numerous annelids (e.g., the first commissure connecting ventral nerve cords [65-70]), as well as in all major clades of gastrotrichs [71-73] and gnathiferans [74-77]. Therefore, the distribution of this character on the phylogenetic tree raises the possibility that the ventral postpharyngeal commissure connecting the major nerve cords might represent a plesiomorphic spiralian trait retained in some form in numerous clades.

\section{Expression of brain patterning genes in Spiralia}

Molecular patterning of the brain has been investigated in relatively many spiralians, representing diverse clades with broad spectrum of morphological complexity of their brains (Table 1). Among those species, the best studied is the annelid Platynereis dumerilii, which possesses a relatively complex brain with multiple morphologically, functionally, and developmentally distinct regions [47, 54, 84-86]. One of the important characteristics of gene expression patterns during the development of the $P$. dumerilii brain is regional restriction of $n k 2.1$ expression to the ventro-median region and pax6 expression in the lateral domains (including eyes and mushroom bodies), with only the minimal overlap of expression of both genes (Fig. 8A [47, 54];). This expression pattern resembles the one observed in vertebrates 


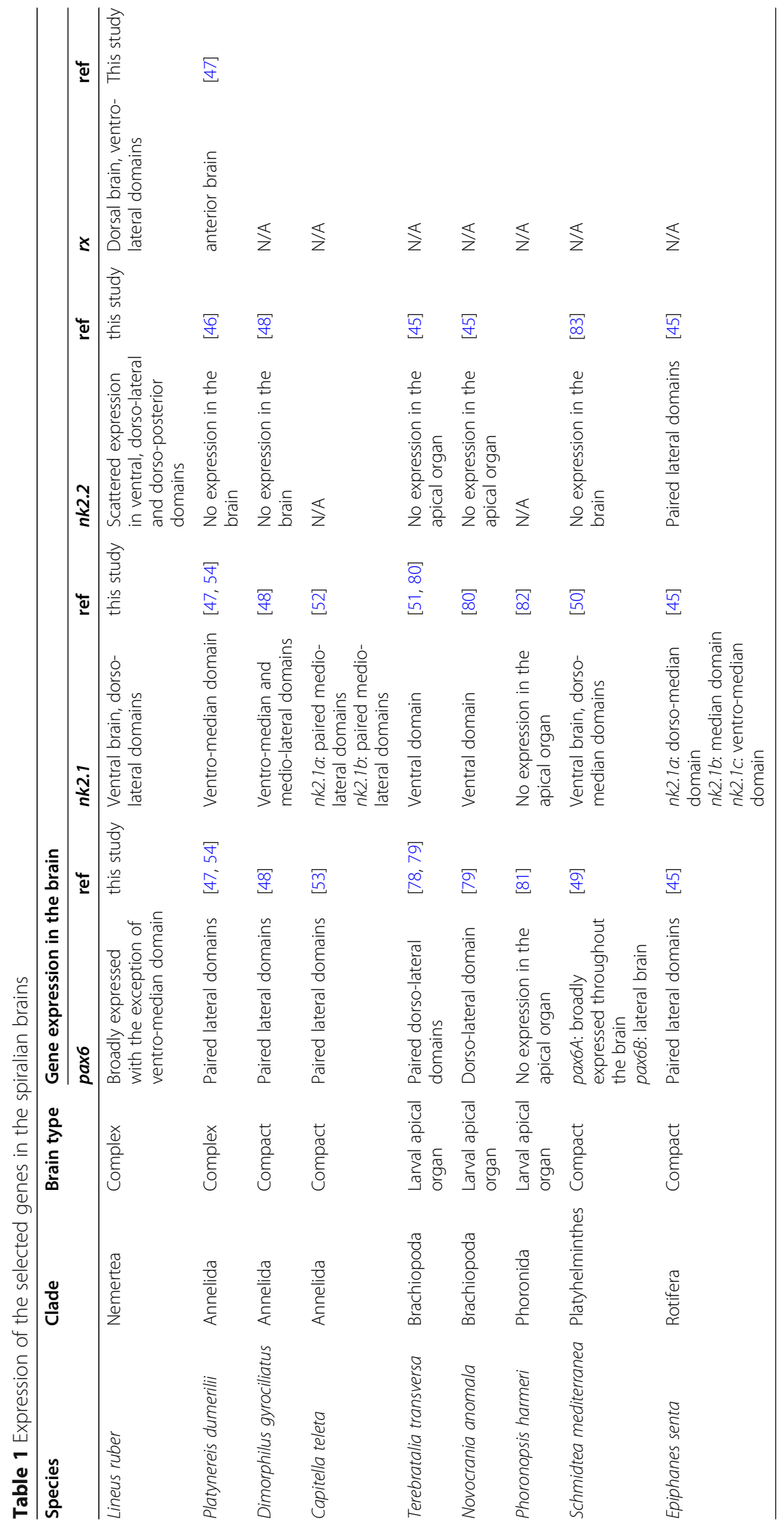




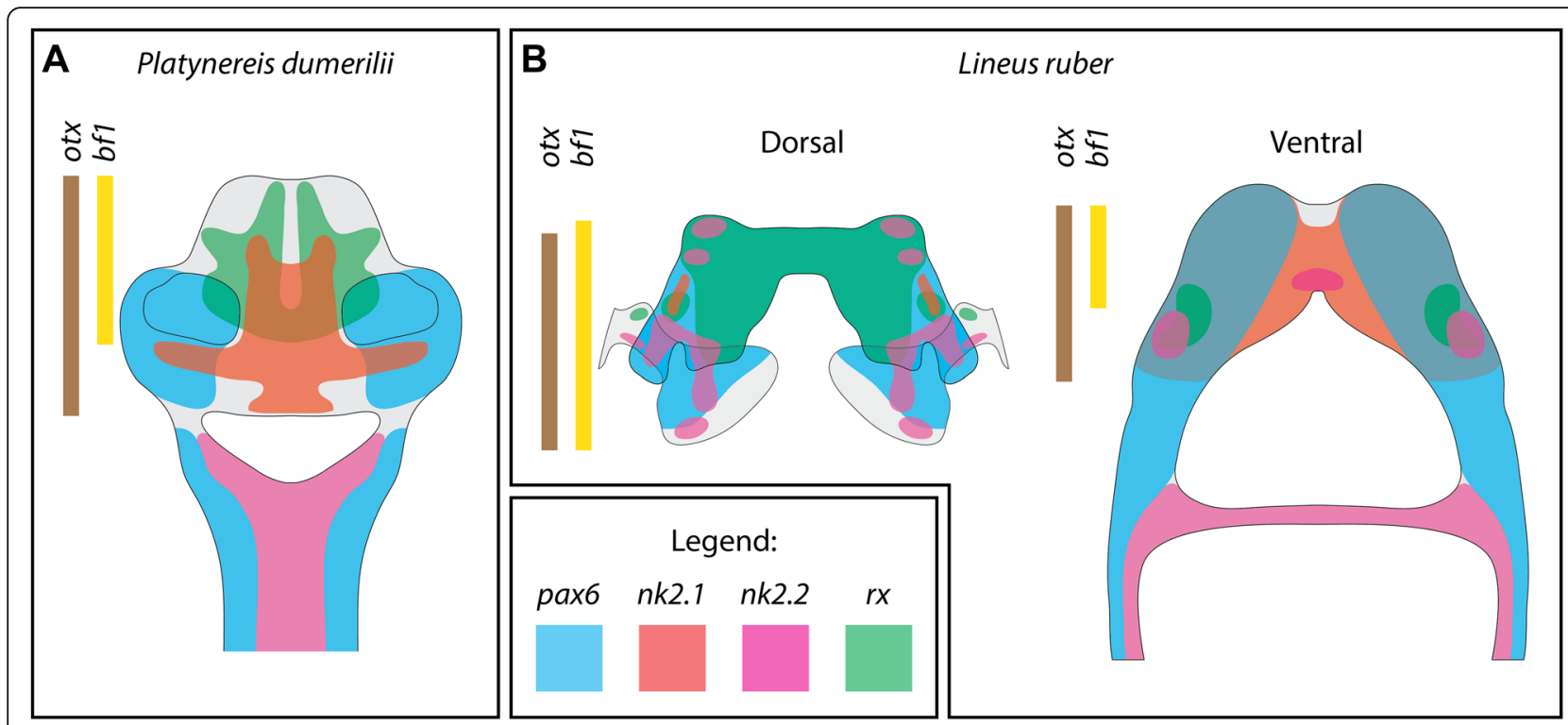

Fig. 8. Comparison of gene expression in the CNS of $\mathbf{A}$ annelid Platynereis dumerilii (based on results from $[46,47,54]$ ) and $\mathbf{B}$ nemertean $L$ ineus ruber (based on current study and [45])

$[87,88]$ and has been proposed as an ancestral bilaterian trait [47]. Although a comparable expression of those two genes is also witnessed in some Spiralia (Table 1), including other annelids [48, 52, 53], rotifers [45], and brachiopods $[45,51,78-80]$, we did not retrieve a similar pattern in either 25- or 42-day-old juveniles of $L$. ruber (Figs. 7B, C, H, I and $8 \mathrm{~B}$ ). $n k 2.1$ is indeed mostly expressed in the ventral domain (Figs. $5 \mathrm{H}$ and 8B), however, it is broadly co-expressed with pax6 in the ventral lobes and in the small dorso-lateral domains (Figs. 7H, J and $8 \mathrm{~B}$ ); while pax6 shows expression not only in the lateral domains but is generally broadly expressed throughout the entire brain (including the dorso-median domain), with the only exception of the small ventromedian region (Figs. 5E, $\mathrm{F}$ and $8 \mathrm{~B}$ ).

A very similar expression of $n k 2.1$ and pax6 has been observed in planarians, where $n k 2.1$ is expressed mostly in the ventral portion of the brain $[49,50]$, while one of the pax6 paralogs, pax6A, is broadly expressed in the brain tissue $[49,89]$. A further parallel between planarians and Lineus is associated with a seemingly diminished role of pax6 in eye formation: pax6 is not expressed during eye development neither in $L$. ruber (this study) nor in L. viridis [90] (although it seems to have a role in eye regeneration in L. sanguineus [90]), while in flatworms eye regeneration has been demonstrated to be pax6 independent [89]. The role of pax6 in eye patterning is otherwise highly conserved among bilaterians (e.g., [91-93]). Due to the unstable position of Nemertea on the spiralian phylogeny (e.g., $[6-8,10])$, it is currently impossible to determine whether those similarities between platyhelminths and nemerteans are due to the convergent evolution, a common evolutionary innovation or retention of ancestral plesiomorphic conditions in both lineages.

A spatially dissimilar gene expression patterns in the brains of various spiralians might be a consequence of cellular movements occurring during organogenesis, which can result in translocation of certain cell types and obliteration of the molecular similarities present in the earlier developmental stages. However, stable spatial expression of several genes in the developing heads of nemertean embryos and juveniles [38] as well as our comparison of gene expression in the early and welldeveloped juvenile brains (Fig. 7) indicate that, at least in $L$. ruber, the molecular patterning is conserved between various developmental stages.

Another important differences in expression of brain patterning genes between $L$. ruber and other Spiralia includes the expression of $n k 2.2$ within numerous brain domains of $L$. ruber (while the gene lacks brain expression not only in annelids $[46,48]$, but also in brachiopods [45] and flatworms [83]) as well as broad expression of $r x$ in the dorsal lobes of the nemertean brain (versus their more rostral expression in P. dumerilii $[47,54])$.

Altogether, this comparison shows that complex brains of nemerteans, and especially their dorsal lobes, show little resemblance in the molecular patterning to the complex brains of $P$. dumerilii (Fig. 8), which in turns seem to share more molecular similarities with simpler brains of other annelids and apical organs of brachiopod larvae (Table 1). This observation, in concert with morphological data [24, 70, 94], indicates that 
complex brains of nemerteans and errant annelids evolved convergently, due to, e.g., similar selective pressure associated with predatory/active life style [95]. We propose that the increase in the brain size and complexity in those two lineages was achieved by independent expansions of non-homologous regions of simpler brains present in their respective ancestors.

Some of the investigated nemertean brain patterning genes are also expressed in the proboscis $(n k 2.1, \mathrm{nk} 2.2$, dach, svp, tll) and rhynchocoel (bf1, arx), two morphological apomorphies of Nemertea [15, 16]. Considering that the proboscis is a highly innervated structure (this study; also $[15-18,22,23,25-28,31,62,63,96]$ ), the neuronal genes in the proboscis might be expressed in the developing neuronal network of the organ. Comparable results were obtained by body region-specific transcriptomics of the nemertean Notospermus geniculatus, in which expression of some of the neuronal markers (e.g., elav, syt12) was also detected in the proboscis [97]. Expression of $a r x$ and $b f 1$ in the rhynchocoel, a coelomderived structure $[16,37]$, seems more peculiar, since those genes have a generally conserved neuroectodermal expression in Bilateria [51, 98-102]. However, arx is also expressed in clade-specific morphological structures of brachiopods (in chaetal sacs and protegulum forming epithelium [103, 104]), annelids (in chaetal sacs [105]), and mollusks (in radula formative tissue [106]). Therefore, our data just further expand the list of potential cooptions of arx into patterning of spiralian evolutionary novelties.

\section{Are mushroom bodies and cerebral organs derived from the same ancestral organs?}

In numerous annelid brains, morphologically distinct structures, referred to as mushroom bodies, are present, which have allegedly chemosensory and cognitive functions [41, 42, 54, 85, 107-112]. There is an ongoing discussion on whether those structures are part of the ancestral annelid body plan or whether they evolved more recently in one of the annelid subclades [41, 85, 113]. However, their phylogenetic distribution (especially the lack of comparable structures in Palaeoannelida and Sedentaria $[70,94,114])$ favors the latter option $[70,94,113,115]$.

Nevertheless, morphologically similar structures are also present in Panarthropoda [42, 110, 116-119], which led some authors to the idea that mushroom bodies-like structures were already present in the common protostome ancestor $[42,54,85,110]$. Although similarities in molecular patterning of annelid mushroom bodies and vertebrate pallium led to the assumption that both structures originated from the same sensory and associative brain center of hypothetical ancestral bilaterians [54], such homology statements, based on observation of only two phylogenetically distant clades, are always at the best case highly tentative $[95,120,121]$.

Cerebral organs of nemerteans, in contrast to the annelid mushroom bodies, can be unequivocally reconstructed as present in the last common nemertean ancestor [23, 25, 30]. However, it remains unresolved whether they are nemertean evolutionary novelty or rather homologs of the mushroom bodies of annelids $[22,41,42]$ or the lateral ciliated pits present in catenulids and macrostomids [32, 40, 43, 122], the two earliest sequentially branching platyhelminth clades [123]. Similarities between the mushroom bodies of annelids and the cerebral organs of nemerteans are rather superficial: the former are integral parts of the brain and are not connected to the external realm, while the latter are always contacting ambient environment and, especially in Hoplonemertea, might be spatially separated from the CNS $[17,30,34,35]$. On the other hand, the function, general morphology, connectivity, and fine structure of cerebral organs of nemerteans and ciliated pits of flatworms bear a strong resemblance [32, 40, 43, 122], making their homology much more likely. Considering the arrangement of the cerebral organs in various nemertean clades, the "ciliated pit" organization seems to represent an ancestral character state also in nemerteans [22-24]. If one accepts that the cerebral organs of nemerteans and ciliated pits of catenulids and macrostomids are homologs [40], then, depending on the phylogenetic position of nemerteans, there are two possible scenarios of their evolution: (1) If nemerteans are sister group to platyhelminths (Parenchymia hypothesis $[7,124]$ ), then the ciliated pits-like structures represent a synapomorphy of Parenchymia. (2) On the other hand, if nemerteans are closer to annelids than flatworms $[5,6,8,10]$, then the presence of ciliated pits might represent a plesiomorphic condition, present also in the annelid ancestor. The latter scenario opens an interesting possibility that ciliated, sensory nuchal organs, present on the prostomium of most annelids [125-127], might be derived from the ancestral spiralian ciliated pits. However, recently it has been suggested that nuchal organs, similarly as mushroom bodies, evolved in one of the annelid in groups and do not represent part of the ancestral annelid body plan [70, 94].

In the face of the above-discussed concerns about the homology of mushroom bodies and cerebral organs, we were surprised to find that cells constituting the cerebral organs express the same set of transcription factors as mushroom bodies of annelids (with both structures being additionally free of $n k 2.1$ expression). Although all nine of the annelid mushroom body markers, whose expression we tested, were expressed in the cerebral organs of L. ruber, they were not co-expressed uniformly throughout the entire structure. Some genes (otx, bf 1 , dach and $t l l$ ) were expressed in all regions of the organ, 
while others were restricted only to some cells in the neuroglandular portion $(p a x 6, e m x, s v p)$ or the ciliated canal $(r x, e m x, a r x)$. The complicated landscape of TFs expression in $L$. ruber correlates well with the fact, that the cerebral organs of 60-day-old juveniles are already composed of numerous diverse cell types, including neurons, glia cells, glandular cells, and ciliated epidermal cells (Fig. 4) as well as still dividing, possibly not fully differentiated, cells (Fig. 3). Unfortunately, with the resolution of our data, we were not able to pinpoint co-expression of particular TFs with specific cell types contributing to the organ. In $P$. dumerilii, these TFs are also not expressed uniformly in the entire mushroom body and show regionalized expression [54]; however, their regionalization does not simply correspond to the one observed in the cerebral organs of $L$. ruber. For example, otx and $t l l$ are expressed only in the subset of neurons constituting mushroom body, while expression of $p a x 6$, arx and $s v p$ is detected in most of the cells forming the organ [54]. Therefore, even though the same set of genes is expressed in both types of organs, their exact co-expression in particular cell types is probably divergent and the apparent similarities in gene expression profiles between both organs might be more superficial than they appear on the first sight.

A further problem with the interpretation of the gene expression patterns in the cerebral organs is related to the fact that, both in annelid and in nemertean, it remains unknown whether those TFs interact in the same gene regulatory network (GRN) or whether they are independently expressed in different, unrelated cell types. If they are part of the same GRN, then co-option of the ancestral regulatory program into patterning of nonhomologs structures might explain the observed similarities. If indeed the ciliated pit-like structures, homologs to the cerebral organs of nemerteans, were present in the annelid ancestor (see above) it is possible to envision a recruitment of the established genetic control of those organs into the patterning of chemoreceptive portion of the brain in the ancestral errant annelid. On the other hand, if the genes are not part of the same GRN and instead act independently in particular cell types (which is supported by non-corresponding, region-specific expression of TFs in mushroom bodies and cerebral organs) a more complicated mechanism might account for the observed similarities. For instance, some of the cell types present in both organs might be homologs derived from the common ancestor, but the organs containing those cell types are convergent and include other, unrelated, and lineage-specific cell types. This could happen due to the reduction of the ciliated duct and the secretory cells and further integration of the neural part of the ancestral ciliated pits with the CNS in annelids. A solid phylogenetic position of Nemertea, analysis of function and interactions of the studied TFs as well as additional gene expression data from catenulids, macrostomids and Palaeoannelida are needed to ascertain on any of those evolutionary scenarios.

\section{Conclusions}

In this study, we investigated the morphology and gene expression in the developing CNS of the nemertean Lineus ruber. At the moment of hatching, juveniles of $L$. ruber have already all major components of the adult nervous system, which indicates that further development is mostly related with increase in the size but not morphological complexity. This likeness correlates well with a similar predatory lifestyle of both juveniles and adults [38]. Comparison of gene expression in the brain of $L$. ruber and the annelid $P$. dumerilii $[46,47,54]$ indicates that complex brains with morphologically and molecularly distinct regions, observed in those two animal species, evolved convergently by independent expansion of non-homologs regions of simpler ancestral brains. Such a scenario corresponds with the similar conclusions drawn by comparative morphology [24, 70, 94]. In contrast to the discrepancies in gene expression in the brains, we observed that the same set of transcription factors, which is expressed in the mushroom bodies of $P$. dumerilii [54] is also expressed in the cerebral organs of L. ruber. These similarities might be a result of convergent recruitment of the same GRN into patterning of nonhomolog organs or indicators of the homology of some cell types contributing to mushroom bodies and cerebral organs that could evolve from the cell type present in the lateral chemosensory ciliated pits of the hypothetical spiralian ancestor. Further studies on the cell-type level and functional interactions of the studied TFs are needed to fully resolve the level of homology, or convergence, between mushroom bodies and cerebral organs.

\section{Methods}

\section{Animal collection and morphological investigation}

Adult specimens of Lineus ruber were collected near Bergen, Norway (Fanafjord; GPS coordinates: 60.251845 $\mathrm{N}, 5.320947 \mathrm{E})$. The animals had dark red coloration with wide pigment-free areas in the terminal part of the head. Animals were kept in the laboratory in filtered seawater at $14{ }^{\circ} \mathrm{C}$ with a daytime cycle: $13 \mathrm{~h}$ of sunshine and $11 \mathrm{~h}$ of darkness. Collection of egg masses and desired developmental stages and animal fixation as well as antibody, nuclear, and EdU stainings followed the already established protocols [38].

Specimens for TEM investigation were fixed in $4 \%$ PFA in PBS, rinsed in the same buffer, postfixed in $1 \%$ OsO4 diluted in $\mathrm{PBS}$ for $120 \mathrm{~min}$ at $4{ }^{\circ} \mathrm{C}$, rinsed again, and dehydrated in graded ethanol/acetone series. The samples were embedded in Epon 812 resin (Sigma Aldrich) and cut to semi- and ultrathin sections with a 
diamond knife (Diatome Histo Jumbo) using ultramicrotome Leica EM UC6. The ultrathin cross-sections of cerebral organ were placed on formvar-covered (Fluka) single slot copper grids and stained with $1 \%$ uranyl acetate and lead citrate.

\section{Gene expression analysis}

Coding sequences for analyzed genes were identified in the transcriptome of $L$. ruber with the reciprocal TBLASTN search using orthologous protein sequences from $P$. dumerilii. Sequence of all of the newly identified genes were translated into protein sequences and aligned with reference sequences from other animals (Table S1). The alignments were trimmed either manually or with TrimAl software [128] and analyzed with FastTree v2.1 [129] in order to assess orthology of the analyzed genes (Figs. S1-5). All newly obtained sequences were submitted to GenBank (Accession numbers MW720144MW720151).

Fragments of genes were amplified from cDNA library using specific primer pairs, cloned into pGEM$T$ Easy vectors (Promega, USA) and then transformed into competent Escherichia coli cells for amplification. Plasmid DNA was isolated and sequenced in both forward and reverse directions using T7 and SP6 primers to assure that the desirable genes were cloned. The antisense probes were transcribed from linearized DNA and labeled either with digoxigenin (for hybridization of single mRNA) or with dinitrophenol (for detection of second gene in double in situ hybridization). Whole mount in situ hybridization followed the same procedure as described for L. ruber juveniles in other studies $[38,45]$.

\section{Imaging and image processing}

Samples for confocal laser scanning microscopy (antibody staining and in situ hybridization) were mounted in Murray's clear and scanned in either Leica SP5 or Olympus FV3000 CLSM. Z-stacks of confocal scans were projected into 2D images in IMARIS 9.1.2. TEM microphotographs were obtained with Gatan ES500W camera mounted on transmission electron microscope Jeol JEM-1011. Both CLSM images and TEM micrographs were assembled in Adobe Illustrator CS6 into final figures. All the schematic drawings were done with Adobe Illustrator CS6.

\section{Supplementary Information}

The online version contains supplementary material available at https://doi. org/10.1186/s12915-021-01113-1.

Additional file 1: Orthology of studied transcription factors

Phylogenetic analyses of protein sequences (Figs. S1- S5) and accession numbers of reference sequences used in alignments (Table S1). Fig. S1.

\section{Acknowledgements}

We are grateful to all present and former members of the Comparative Developmental Biology Group, University of Bergen, who helped with the collection and culturing of Lineus ruber. We also would like to thank Naëlle Barabé, who cloned and prepared probe against dach gene. All TEM studies were carried out at the Shared Research Facility "Electron microscopy in life sciences" at Moscow State University.

\section{Authors' contributions}

LG conducted gene search and orthology assessments, cloned genes, performed in situ hybridization, arranged figures, and drafted the manuscript. AB performed antibody staining, searched and cloned genes, and performed in situ hybridization. IAC prepared, examined, and photographed samples for TEM. AOA searched and cloned genes and performed antibody and EdU stainings. AH designed and coordinated the study and contributed to the writing. The authors read and approved the final manuscript.

\section{Funding}

Research was supported by the European Research Council Community's Framework Program Horizon 2020 (2014-2020) ERC grant agreement 648861 and the Norwegian Research Council FRIPRO grant 815194 to AH.

\section{Availability of data and materials}

Sequences generated and analyzed in this study have been deposited in NCBI's GenBank database under accession numbers MW720144-MW720151. All remaining data generated or analyzed during this study are included in this article or its supplementary materials.

\section{Declarations}

Ethics approval and consent to participate

Studies of nemerteans do not require ethics approval or consent to participate.

\section{Consent for publication}

Not applicable.

\section{Competing interests}

The authors declare that they have no competing interests.

\section{Author details}

'Department of Biological Sciences, University of Bergen, Bergen, Norway. ${ }^{2}$ Biological Faculty, M.V. Lomonosov Moscow State University Moscow, Russia.

Received: 1 April 2021 Accepted: 30 July 2021

Published online: 27 August 2021

\section{References}

1. Giribet G, Edgecombe GD. Nemertea. In: The invertebrate tree of life. Princeton and Oxford: Princeton University Press; 2020. p. 412-23. https:// doi.org/10.1515/9780691197067-050.

2. Kajihara H, Chernyshev AV, Sun S-C, Sundberg P, Crandall FB. Checklist of nemertean genera and species published between 1995 and 2007. Species Diversity. 2008;13(4):245-74. https://doi.org/10.12782/specdiv.13.245.

3. Gibson R. Nemertean genera and species of the world: an annotated checklist of original names and description citations, synonyms, current taxonomic status, habitats and recorded zoogeographic distribution. J Nat Hist. 1995;29(2):271-561. https://doi.org/10.1080/00222939500770161.

4. Dunn CW, Hejnol A, Matus DQ, Pang K, Browne WE, Smith SA, Seaver E, Rouse GW, Obst M, Edgecombe GD, et al. Broad phylogenomic sampling improves resolution of the animal tree of life. Nature. 2008:452(7188):745-9. https://doi.org/10.1038/nature06614.

5. Laumer CE, Bekkouche N, Kerbl A, Goetz F, Neves RC, Sørensen MV, et al. Spiralian phylogeny informs the evolution of microscopic lineages. Curr Biol. 2015;25(15):2000-6. https://doi.org/10.1016/j.cub.2015.06.068.

6. Laumer CE, Fernandez R, Lemer S, Combosch D, Kocot KM, Riesgo A, et al. Revisiting metazoan phylogeny with genomic sampling of all phyla. Proc Biol Sci. 2019;286(1906):20190831. 
7. Marlétaz F, Peijnenburg K, Goto T, Satoh N, Rokhsar DS. A new spiralian phylogeny places the enigmatic arrow worms among gnathiferans. Curr Biol. 2019;29(2):312-8 e313. https://doi.org/10.1016/j.cub.2018.11.042.

8. Zverkov OA, Mikhailov KV, Isaev SV, Rusin LY, Popova OV, Logacheva MD, et al. Dicyemida and orthonectida: two stories of body plan simplification. Front Genet. 2019;10:443. https://doi.org/10.3389/fgene.2019.00443.

9. Hejnol A, Obst M, Stamatakis A, Ott M, Rouse GW, Edgecombe GD, et al. Assessing the root of bilaterian animals with scalable phylogenomic methods. Proc R Soc B Biol Sci. 2009;276(1677):4261-70. https://doi.org/10.1 098/rspb.2009.0896.

10. Kocot KM, Struck TH, Merkel J, Waits DS, Todt C, Brannock PM, et al. Phylogenomics of lophotrochozoa with consideration of systematic error. Syst Biol. 2017;66(2):256-82. https://doi.org/10.1093/sysbio/syw079.

11. Struck $T H$, Fisse F. Phylogenetic position of nemertea derived from phylogenomic data. Mol Biol Evol. 2008;25(4):728-36. https://doi.org/10.1 093/molbev/msn019.

12. Giribet G, Dunn CW, Edgecombe GD, Hejnol A, Martindale MQ, Rouse GW Assembling the spiralian tree of life. In: Littlewood DTJ, Telford MJ, editors. Animal evolution: genomes, fossils and trees. Oxford: Oxford University Press; 2009. p. 52-64

13. Bleidorn C. Recent progress in reconstructing lophotrochozoan (spiralian) phylogeny. Org Divers Evol. 2019:1-10.

14. von Döhren J. Nemertea. In: Wanninger A, editor. Evolutionary developmental biology of invertebrates 2. Vienna: Springer; 2015. p 155-192.

15. Chernyshev AV. CLSM analysis of the phalloidin-stained muscle system of the nemertean proboscis and rhynchocoel. Zool Sci. 2015;32(6):547-60. https://doi.org/10.2108/zs140267.

16. Turbeville J, Ruppert E. Comparative ultrastructure and the evolution of nemertines. Am Zool. 1985;25(1):53-71. https://doi.org/10.1093/icb/25.1.53.

17. Mclntosh WC. A monograph of the British annelids: the Nemerteans. London: Ray Society; 1874.

18. Bürger O: Die Nemertinen des Golfes von Neapel und der angrenzenden Meeres-Abschnitte, vol. 1: Engelmann; 1895.

19. Thiel $D$, Bauknecht $P$, Jékely $G$, Hejnol A. A nemertean excitatory peptide/ CCHamide regulates ciliary swimming in the larvae of Lineus longissimus. Front Zool. 2019:16(1):28. https://doi.org/10.1186/s12983-019-0326-9.

20. Thiel D, Guerra LAY, Franz-Wachtel M, Hejnol A, Jékely G. Nemertean, brachiopod and phoronid neuropeptidomics reveals ancestral spiralian signalling systems. Mol Biol Evol. 2021. https://doi.org/10.1093/molbev/msab211.

21. Punin MY, Zaitseva OV, Markosova TG. First data on monoamine- and peptidecontaining elements of the nervous system of nemertines. Dokl Biol Sci. 2003; 393(1-6):565-7. https://doi.org/10.1023/B:DOBS.0000010325.39269.09.

22. Beckers P, Faller S, Loesel R. Lophotrochozoan neuroanatomy: an analysis of the brain and nervous system of Lineus viridis (Nemertea) using different staining techniques. Front Zool. 2011;8(1):17. https://doi.org/10.1186/17429994-8-17.

23. Beckers P. Nemertean nervous system: a comparative analysis. Bonn: Universitäts-und Landesbibliothek Bonn; 2011.

24. Beckers $P$, Loesel $R$, Bartolomaeus $T$. The nervous systems of basally branching nemertea (palaeonemertea). PLoS One. 2013;8(6):e66137. https:// doi.org/10.1371/journal.pone.0066137.

25. Beckers P. The nervous systems of Pilidiophora (Nemertea). Zoomorphology. 2015:134(1):1-24. https://doi.org/10.1007/s00435-014-0246-3.

26. Zaitseva OV, Petrov SA, Petrov AA. Sensory systems of Lineus ruber (Nemertea, Pilidiophora). Zoomorphology. 2020;139(4):447-59. https://doi. org/10.1007/s00435-020-00502-4.

27. Zaitseva OV, Markosova TG. Choline acetyltransferase and NADPHdiaphorase activity in the nervous system and receptor organs of nemerteans. Dokl Biol Sci. 2009;428(1):427-9. https://doi.org/10.1134/S00124 9660905010X.

28. Zaitseva OV, Petrov SA. Biogenic amines in the nervous system of nemerteans. Dokl Biol Sci. 2013;451(1):228-30. https://doi.org/10.1134/ S001249661304008X

29. Gibson R: Nemerteans, vol. 178: Hutchinson; 1972

30. Beckers $P$, Krämer D, Bartolomaeus T. The nervous systems of Hoplonemertea (Nemertea). Zoomorphology. 2018;137(4):473-500. https:/ doi.org/10.1007/s00435-018-0414-y.

31. Punnett RC. Lineus, vol. VII. London: Williams \& Norgate; 1901.

32. Ling EA. The structure and function of the cephalic organ of a nemertine Lineus ruber. Tissue Cell. 1969:1 (3):503-24. https://doi.org/10.1016/S0040-81 66(69)80019-4.
33. Ling EA. Further investigations on the structure and function of cephalic organs of a nemertine Lineus ruber. Tissue Cell. 1970;2(4):569-88. https://doi. org/10.1016/50040-8166(70)80031-3.

34. Ferraris JD. Putative neuroendrocrine devices in the nemertina -an overview of structure and function. Am Zool. 1985;25(1):73-85. https://doi. org/10.1093/icb/25.1.73.

35. Amerongen HM, Chia FS. Fine structure of the cerebral organs in hoplonemerteans (Nemertini), with a discussion of their function Zoomorphology. 1987;107(3):145-59. https://doi.org/10.1007/BF00312308.

36. Schmidt G. Embryonic development of littoral nemertines Lineus desori (mihi, species nova) and Lineus ruber (OF Mülleri, 1774, GA Schmidt, 1945) in connection with ecological relation changes of mature individuals when forming the new species Lineus ruber. Zool Pol. 1964(14):75-122.

37. Maslakova SA. Development to metamorphosis of the nemertean pilidium larva. Front Zool. 2010;7(1):30. https://doi.org/10.1186/1742-9994-7-30.

38. Martin-Duran JM, Vellutini BC, Hejnol A. Evolution and development of the adelphophagic, intracapsular Schmidt's larva of the nemertean Lineus ruber. Evodevo. 2015;6(1):28. https://doi.org/10.1186/s13227-015-0023-5.

39. Hindinger S, Schwaha T, Wanninger A. Immunocytochemical studies reveal novel neural structures in nemertean pilidium larvae and provide evidence for incorporation of larval components into the juvenile nervous system. Front Zool. 2013;10(1):31. https://doi.org/10.1186/1742-9994-10-31.

40. Kepner WA, Taliaferro W. Sensory epithelium of pharynx and ciliated pits of Microstoma caudatum. Biol Bull. 1912;23(1):42-59. https://doi.org/10.2307/1 536003.

41. Loesel R, Heuer CM. The mushroom bodies-prominent brain centres of arthropods and annelids with enigmatic evolutionary origin. Acta Zool. 2010;91(1):29-34. https://doi.org/10.1111/j.1463-6395.2009.00422.x.

42. Wolff GH, Strausfeld NJ. Genealogical correspondence of mushroom bodies across invertebrate phyla. Curr Biol. 2015;25(1):38-44. https://doi.org/10.101 6/j.cub.2014.10.049.

43. Kepner WA, Cash J. Ciliated pits of Stenostoma. J Morphol. 1915;26(2):23545. https://doi.org/10.1002/jmor.1050260204.

44. Nusbaum J, Oxner M. Die Embryonalentwicklung des Lineus ruber Müll. Ein Beitrag Zur Entwicklungsgeschichte der Nemertinen. Z Wiss Zool. 1913;107:78-197.

45. Martin-Duran JM, Pang K, Børve A, Semmler Lê H, Furu A, Cannon JT, et al. Convergent evolution of bilaterian nerve cords. Nature. 2018;553(7686):45-50. https://doi.org/10.1038/nature25030.

46. Denes AS, Jékely G, Steinmetz PRH, Raible F, Snyman H, Prud'homme B, et al. Molecular architecture of annelid nerve cord supports common origin of nervous system centralization in Bilateria. Cell. 2007;129(2):277-88. https://doi.org/10.1016/j.cell.2007.02.040.

47. Tessmar-Raible K, Raible F, Christodoulou F, Guy K, Rembold M, Hausen H, et al. Conserved sensory-neurosecretory cell types in annelid and fish forebrain: insights into hypothalamus evolution. Cell. 2007;129(7):1389-400. https://doi.org/10.1016/j.cell.2007.04.041.

48. Kerbl A, Martin-Duran JM, Worsaae K, Hejnol A. Molecular regionalization in the compact brain of the meiofaunal annelid Dinophilus gyrociliatus (Dinophilidae). EvoDevo. 2016;7(1):1-21.

49. Scimone ML, Kravarik KM, Lapan SW, Reddien PW. Neoblast specialization in regeneration of the planarian Schmidtea mediterranea. Stem cell reports. 2014;3(2):339-52. https://doi.org/10.1016/j.stemcr.2014.06.001.

50. Currie KW, Molinaro AM, Pearson BJ. Neuronal sources of hedgehog modulate neurogenesis in the adult planarian brain. Elife. 2016;5:e19735. https://doi.org/10.7554/eLife.19735.

51. Santagata S, Resh C, Hejnol A, Martindale MQ, Passamaneck YJ, Development of the larval anterior neurogenic domains of Terebratalia transversa (Brachiopoda) provides insights into the diversification of larval apical organs and the spiralian nervous system. Evodevo. 2012;3(1):1-21.

52. Boyle MJ, Yamaguchi E, Seaver EC. Molecular conservation of metazoan gut formation: evidence from expression of endomesoderm genes in Capitella teleta (Annelida). EvoDevo. 2014;5(1):1-19.

53. Klann M, Seaver EC. Functional role of pax6 during eye and nervous system development in the annelid Capitella teleta. Dev Biol. 2019:456(1):86-103. https://doi.org/10.1016/j.ydbio.2019.08.011

54. Tomer R, Denes AS, Tessmar-Raible K Arendt D. Profiling by image registration reveals common origin of annelid mushroom bodies and vertebrate pallium. Cell. 2010:142(5):800-9. https:/doi.org/10.1016/j.cell.2010.07.043.

55. Oda Y. Choline acetyltransferase: the structure, distribution and pathologic changes in the central nervous system. Pathol Int. 1999:49(11):921-37. https://doi.org/10.1046/j.1440-1827.1999.00977.x. 
56. Richter S, Loesel R, Purschke G, Schmidt-Rhaesa A, Scholtz G, Stach T, et al. Invertebrate neurophylogeny: suggested terms and definitions for a neuroanatomical glossary. Front Zool. 2010;7(1):29. https://doi.org/10.1186/1 742-9994-7-29.

57. Charpignon V: Homeobox-containing genes in the nemertean Lineus: key players in the antero-posterior body patterning and in the specification of the visual structures. Reims; 2006.

58. Krämer D, Schmidt C, Podsiadlowski L, Beckers P, Horn L, von Döhren J. Unravelling the Lineus ruber/viridis species complex (Nemertea, Heteronemertea). Zool Scr. 2017;46(1):111-26. https://doi.org/10.1111/zsc.12185.

59. Cherneva IA, Chernyshev AV, Ekimova IA, Polyakova NE, Schepetov DM, Turanov SV, et al. Species identity and genetic structure of nemerteans of the "Lineus ruber-viridis" complex (Muller, 1774) from Arctic waters (vol 42, pg 497, 2019). Polar Biol. 2019;42(3):507-8. https://doi.org/10.1007/s00300-018-02449-1.

60. von Döhren J. Development of the nervous system of Carinina ochracea (Palaeonemertea, Nemertea). PLoS One. 2016;11(10):e0165649.

61. Coe WR. The nervous system of pelagic nemerteans. Biol Bull. 1927;53(2): 123-38. https://doi.org/10.2307/1537033.

62. Sundberg $P$, Chernyshev AV, Kajihara H, Kanneby T, Strand M. Character-matrix based descriptions of two new nemertean (Nemertea) species. Zool J Linnean Soc. 2009;157(2):264-94. https://doi.org/10.1111/j.1096-3642.2008.00514.x.

63. Stricker SA. The morphology of Paranemertes sanjuanensis sp. n.(Nemertea, Monostilifera) from Washington, USA. Zool Scr. 1982;11(2):107-15. https://doi.org/10.1111/j.1463-6409.1982.tb00523.x.

64. von Döhren J, et al. Front Ecol Evol. 2021;9:232.

65. Helm C, Beckers P, Bartolomaeus T, Drukewitz SH, Kourtesis I, Weigert A, et al. Convergent evolution of the ladder-like ventral nerve cord in Annelida. Front Zool. 2018;15(1). https://doi.org/10.1186/s12983-018-0280-y.

66. Orrhage L, Müller MCM. Morphology of the nervous system of Polychaeta (Annelida). Hydrobiologia. 2005;535:79-111.

67. Kerbl A, Bekkouche N, Sterrer W, Worsaae K. Detailed reconstruction of the nervous and muscular system of Lobatocerebridae with an evaluation of its annelid affinity. BMC Evol Biol. 2015;15(1):277. https://doi.org/10.1186/s12 862-015-0531-x

68. Meyer NP, Carrillo-Baltodano A, Moore RE, Seaver EC. Nervous system development in lecithotrophic larval and juvenile stages of the annelid Capitella teleta. Front Zool. 2015;12(1):15. https:/doi.org/10.1186/s12983-015-0108-y.

69. Carrillo-Baltodano AM, Boyle MJ, Rice ME, Meyer NP. Developmental architecture of the nervous system in Themiste lageniformis (Sipuncula): new evidence from confocal laser scanning microscopy and gene expression. J Morphol. 2019;280(11):1628-50. https://doi.org/10.1002/jmor.21054.

70. Beckers P, Helm C, Purschke G, Worsaae K, Hutchings P, Bartolomaeus T. The central nervous system of Oweniidae (Annelida) and its implications for the structure of the ancestral annelid brain. Front Zool. 2019;16(1):1-21.

71. Todaro MA, Dal Zotto M, Leasi F. An integrated morphological and molecular approach to the description and systematisation of a novel genus and species of Macrodasyida (Gastrotricha). PLoS One. 2015;10(7):e0130278.

72. Rothe BH, Schmidt-Rhaesa A, Kieneke A. The nervous system of Neodasys chaetonotoideus (Gastrotricha: Neodasys) revealed by combining confocal laserscanning and transmission electron microscopy: evolutionary comparison of neuroanatomy within the Gastrotricha and basal Protostomia. Zoomorphology. 2011;130(1):51-84. https://doi.org/10.1007/s00435-011-0123-2.

73. Bekkouche N, Worsaae K. Neuromuscular study of early branching Diuronotus aspetos (Paucitubulatina) yields insights into the evolution of organs systems in Gastrotricha. Zoological Lett. 2016;2(1):21. https://doi. org/10.1186/s40851-016-0054-3.

74. Gąsiorowski L, Bekkouche N, Worsaae K. Morphology and evolution of the nervous system in Gnathostomulida (Gnathifera, Spiralia). Org Divers Evol. 2017:17(2):447-75. https://doi.org/10.1007/s13127-017-0324-8.

75. Bekkouche N, Worsaae K. Nervous system and ciliary structures of Micrognathozoa (Gnathifera): evolutionary insight from an early branch in Spiralia. Roy Soc Open Sci. 2016;3(10):160289. https://doi.org/10.1098/rsos.160289.

76. Gąsiorowski L, Furu A, Hejnol A. Morphology of the nervous system of monogonont rotifer Epiphanes senta with a focus on sexual dimorphism between feeding females and dwarf males. Front Zool. 2019;16(1):1-13.

77. Hochberg R. Topology of the nervous system of Notommata copeus (Rotifera: Monogononta) revealed with anti-FMRFamide,-SCPb, andserotonin (5-HT) immunohistochemistry. Invertebr Biol. 2007;126(3):247-56. https://doi.org/10.1111/j.1744-7410.2007.00094.x.

78. Passamaneck YJ, Furchheim N, Hejnol A, Martindale MQ, Lüter C. Ciliary photoreceptors in the cerebral eyes of a protostome lanva. EvoDevo. 2011;2(1):1-18.
79. Vellutini BC, Hejnol A. Expression of segment polarity genes in brachiopods supports a non-segmental ancestral role of engrailed for bilaterians. Sci Rep. 2016;6(1):1-15.

80. Martin-Duran JM, Passamaneck YJ, Martindale MQ, Hejnol A. The developmental basis for the recurrent evolution of deuterostomy and protostomy. Nat Ecol Evol. 2017;1(1):1-10. https://doi.org/10.1038/s41559-016-0005.

81. Gąsiorowski L, Hejnol A. Hox gene expression during development of the phoronid Phoronopsis harmeri. EvoDevo. 2020;11(1):2. https://doi.org/10.11 86/s13227-020-0148-z

82. Andrikou C, Passamaneck YJ, Lowe CJ, Martindale MQ, Hejnol A. Molecular patterning during the development of Phoronopsis harmeri reveals similarities to rhynchonelliform brachiopods. EvoDevo. 2019;10(1):1-15.

83. Forsthoefel DJ, James NP, Escobar DJ, Stary JM, Vieira AP, Waters FA, et al. An RNAi screen reveals intestinal regulators of branching morphogenesis, differentiation, and stem cell proliferation in planarians. Dev Cell. 2012;23(4): 691-704. https://doi.org/10.1016/j.devcel.2012.09.008.

84. Orrhage L. On the microanatomy of the cephalic nervous system of Nereidae (Polychaeta), with a preliminary discussion of some earlier theories on the segmentation of the polychaete brain. Acta Zool. 1993;74(2):145-72. https://doi.org/10.1111/j.1463-6395.1993.tb01231.x.

85. Heuer CM, Müller CHG, Todt C, Loesel R. Comparative neuroanatomy suggests repeated reduction of neuroarchitectural complexity in Annelida. Front Zool. 2010;7(1):13. https://doi.org/10.1186/1742-9994-7-13.

86. Williams EA, Verasztó C, Jasek S, Conzelmann M, Shahidi R, Bauknecht P, et al. Synaptic and peptidergic connectome of a neurosecretory center in the annelid brain. Elife. 2017;6:e26349. https://doi.org/10.7554/eLife.26349.

87. Murakami Y, Ogasawara M, Sugahara F, Hirano S, Satoh N, Kuratani S. Identification and expression of the lamprey Pax6 gene: evolutionary origin of the segmented brain of vertebrates. Development. 2001;128(18):3521-31. https://doi.org/10.1242/dev.128.18.3521.

88. Corbin JG, Rutlin M, Gaiano N, Fishell G. Combinatorial function of the homeodomain proteins Nkx2.1 and Gsh2 in ventral telencephalic patterning. Development. 2003;130(20):4895-906. https://doi.org/10.1242/dev.00717.

89. Pineda D, Rossi L, Batistoni R, Salvetti A, Marsal M, Gremigni V, et al. The genetic network of prototypic planarian eye regeneration is Pax6 independent. Development. 2002:129(6):1423-34. https://doi.org/10.1242/dev.129.6.1423.

90. Loosli F, Kmita-Cunisse M, Gehring WJ. Isolation of a Pax-6 homolog from the ribbonworm Lineus sanquineus. Proc Natl Acad Sci USA. 1996;93(7): 2658-63. https://doi.org/10.1073/pnas.93.7.2658.

91. Gehring WJ, Ikeo K. Pax 6: mastering eye morphogenesis and eye evolution. Trends Genet. 1999;15(9):371-7. https://doi.org/10.1016/S0168-9525(99)01776-X.

92. Quiring R, Walldorf U, Kloter U, Gehring WJ. Homology of the eyeless gene of Drosophila to the small eye gene in mice and Aniridia in humans. Science. 1994:265(5173):785-9. https://doi.org/10.1126/science.7914031.

93. Kozmik Z. Pax genes in eye development and evolution. Curr Opin Genet Dev. 2005;15(4):430-8. https://doi.org/10.1016/j.gde.2005.05.001

94. Beckers P, Helm C, Bartolomaeus T. The anatomy and development of the nervous system in Magelonidae (Annelida)-insights into the evolution of the annelid brain. BMC Evol Biol. 2019:19(1):1-21.

95. Hejnol A, Lowe CJ. Embracing the comparative approach: how robust phylogenies and broader developmental sampling impacts the understanding of nervous system evolution. Phil Trans R Soc B. 2015;370:20150045.

96. Magarlamov TY, Chernyshev AV. Ultrastructural study of the proboscis of Malacobdella grossa (Nemertea: Hoplonemertea). J Nat Hist. 2010;44(37-40): 2349-61. https://doi.org/10.1080/00222933.2010.504894.

97. Luo YJ, Kanda M, Koyanagi R, Hisata K, Akiyama T, Sakamoto H, et al. Nemertean and phoronid genomes reveal lophotrochozoan evolution and the origin of bilaterian heads. Nat Ecol Evol. 2018;2(1):141-51. https://doi. org/10.1038/s41559-017-0389-y.

98. Kumamoto T, Hanashima C. Evolutionary conservation and conversion of Foxg1 function in brain development. Dev Growth Differ. 2017;59(4):258-69. https://doi.org/10.1111/dgd.12367.

99. Miura H, Yanazawa M, Kato K, Kitamura K. Expression of a novel aristaless related homeobox gene 'Arx'in the vertebrate telencephalon, diencephalon and floor plate. Mech Dev. 1997;65(1-2):99-109. https://doi.org/10.1016/S092 5-4773(97)00062-2.

100. Gécz J, Cloosterman D, Partington M. ARX: a gene for all seasons. Curr Opin Genet Dev. 2006;16(3):308-16. https://doi.org/10.1016/j.gde.2006.04.003.

101. Melkman T, Sengupta P. Regulation of chemosensory and GABAergic motor neuron development by the C. elegans Aristaless/Arx homolog alr-1. Development. 2005;132(8):1935-49. https://doi.org/10.1242/dev.01788. 
102. Melkman TJ. Studying neuronal development in Caenorhabditis elegans: The role of the ARX homolog, alr-1. Doctoral dissertation, Brandeis University; 2005.

103. Schiemann SM, Martin-Duran JM, Børve A, Vellutini BC, Passamaneck YJ, Hejnol A. Clustered brachiopod Hox genes are not expressed collinearly and are associated with lophotrochozoan novelties. Proc Natl Acad Sci U S A. 2017;114(10):E1913-22. https://doi.org/10.1073/pnas.1614501114.

104. Gąsiorowski L, Hejnol A. Hox gene expression in postmetamorphic juveniles of the brachiopod Terebratalia transversa. EvoDevo. 2019;10(1):1. https://doi. org/10.1186/s13227-018-0114-1.

105. Fischer A: Mesoderm formation and muscle development of Platynereis dumerilli (Nereididae, Annelida). Freie Universität Berlin; 2010.

106. Hilgers L, Hartmann S, Hofreiter M, von Rintelen T. Novel genes, ancient genes, and gene co-option contributed to the genetic basis of the radula, a molluscan innovation. Mol Biol Evol. 2018;35(7):1638-52. https://doi.org/10.1 093/molbev/msy052.

107. Holmgren NF: Zur vergleichenden anatomie des gehirns: von polychaeten onychophoren, xiphosuren, arachniden, crustaceen, myriapoden und insekten. Vorstudien zu einer phylogenie der anthropoden, vol. 56: Kungl Svenska Vetenskaps Handl 1916.

108. Hanström B. Untersuchungen über die relative Größe der Gehirnzentren verschiedener Arthropoden unter Berücksichtigung der Lebensweise. Z Mikr Anat Forsch. 1926;7:139-90.

109. Hanström B. Vergleichende Anatomie des Nervensystems der wirbellosen Tiere. Berlin, Heidelberg, New York: Julius Springer; 1928.

110. Strausfeld NJ, Hansen L, Li Y, Gomez RS, Ito K. Evolution, discovery, and interpretations of arthropod mushroom bodies. Learn Mem. 1998;5(1):11-37.

111. Heuer C, Loesel R. Three-dimensional reconstruction of mushroom body neuropils in the polychaete species Nereis diversicolor and Harmothoe areolata (Phyllodocida, Annelida). Zoomorphology. 2009;128(3):219-26. https://doi.org/10.1007/s00435-008-0063-7.

112. Heuer C, Loesel R. Immunofluorescence analysis of the internal brain anatomy of Nereis diversicolor (Polychaeta, Annelida). Cell Tissue Res. 2008; 331(3):713-24. https://doi.org/10.1007/s00441-007-0535-y.

113. Purschke G, Bleidorn C, Struck T. Systematics, evolution and phylogeny of Annelida-a morphological perspective. Mem Museum Victoria. 2014;71:24769. https://doi.org/10.24199/j.mmv.2014.71.19.

114. Rimskaya-Korsakova NN, Kristof A, Malakhov W, Wanninger A. Neural architecture of Galathowenia oculata Zach, 1923 (Oweniidae, Annelida). Front Zool. 2016;13(1):1-19.

115. Schmidbaur H, Schwaha T, Franzkoch R, Purschke G, Steiner G. Within-family plasticity of nervous system architecture in Syllidae (Annelida, Errantia). Front Zool. 2020;17(1):1-44.

116. Flögel JHL. Über den feineren Bau des Arthropodengehirns. Tageblatt der Versammlung Deutscher Naturforscher und Ärzte. 1876;49:115-20.

117. Kenyon F. The meaning and structure of the so-called "mushroom bodies" of the hexapod brain. Am Nat. 1896;30(356):643-50. https://doi.org/10.1086/276450

118. Strausfeld NJ, Mok Strausfeld C, Loesel R, Rowell D, Stowe S. Arthropod phylogeny: onychophoran brain organization suggests an archaic relationship with a chelicerate stem lineage. Proc R Soc B Biol Sci. 2006; 273(1596):1857-66. https://doi.org/10.1098/rspb.2006.3536.

119. Strausfeld NJ, Mok Strausfeld C, Stowe S, Rowell D, Loesel R. The organization and evolutionary implications of neuropils and their neurons in the brain of the onychophoran Euperipatoides rowelli. Arthropod Struct Dev. 2006;35(3):169-96. https://doi.org/10.1016/j.asd.2006.06.002.

120. Church SH, Extavour CG. Null hypotheses for developmental evolution. Development. 2020;147(8):dev178004.

121. Martín-Durán JM, Hejnol A. A developmental perspective on the evolution of the nervous system. Dev Biol. 2021;475:181-92. https://doi.org/10.1016/j. ydbio.2019.10.003.

122. Ott HN. A study of Stenostoma leucops O. Schm J Morph. 1892;7(3):263-304. https://doi.org/10.1002/jmor.1050070302.

123. Laumer $C E$, Hejnol A, Giribet $G$, et al. Nuclear genomic signals of the 'microturbellarian' roots of platyhelminth evolutionary innovation elife. 2015; 4:e05503. https://doi.org/10.7554/eLife.05503.

124. Nielsen C. Animal evolution. Interrelationships of the living phyla. Oxford (UK): Oxford University Press; 1995.

125. Purschke G. Sense organs in polychaetes (Annelida). Hydrobiologia. 2005; 535(1):53-78.

126. Purschke G. Ultrastructure of nuchal organs in polychaetes (Annelida) —new results and review. Acta Zool. 1997;78(2):123-43. https://doi.org/10.1111/j.14 63-6395.1997.tb01133.x.
127. Rhode B. Ultrastructure of nuchal organs in some marine polychaetes. J Morphol. 1990;206(1):95-107. https://doi.org/10.1002/jmor.1052060110.

128. Capella-Gutierrez S, Silla-Martinez JM. Gabaldon T: trimAl: a tool for automated alignment trimming in large-scale phylogenetic analyses. Bioinformatics. 2009; 25(15):1972-3. https://doi.org/10.1093/bioinformatics/btp348.

129. Price MN, Dehal PS, Arkin AP. FastTree 2-approximately maximum-likelihood trees for large alignments. PLoS One. 2010;5(3):e9490.

\section{Publisher's Note}

Springer Nature remains neutral with regard to jurisdictional claims in published maps and institutional affiliations.
Ready to submit your research? Choose BMC and benefit from:

- fast, convenient online submission

- thorough peer review by experienced researchers in your field

- rapid publication on acceptance

- support for research data, including large and complex data types

- gold Open Access which fosters wider collaboration and increased citations

- maximum visibility for your research: over $100 \mathrm{M}$ website views per year

At BMC, research is always in progress.

Learn more biomedcentral.com/submissions 